\title{
AKT Hyperactivation and the Potential of AKT-Targeted Therapy in Diffuse Large B-Cell Lymphoma
}

Jinfen Wang, ${ }^{* \dagger}$ Zijun Y. Xu-Monette, ${ }^{*}$ Kausar J. Jabbar, ${ }^{\star}$ Qi Shen, ${ }^{*}$ Ganiraju C. Manyam, ${ }^{\ddagger}$ Alexandar Tzankov, ${ }^{\S}$ Carlo Visco,, Jing Wang, Santiago Montes-Moreno, "Karen Dybkær, ${ }^{* *}$ Wayne Tam, ${ }^{\dagger \dagger}$ Govind Bhagat, ${ }^{\ddagger}$ Eric D. Hsi, ${ }^{\S \S}$ J. Han van Krieken, ${ }^{\mp 9}$ Maurilio Ponzoni, \|\|$\|$ Andrés J.M. Ferreri, \|\| $\mid$ Shi Wang, ${ }^{* * *}$ Michael B. Møller, ${ }^{\dagger \dagger \dagger}$ Miguel A. Piris, L. Jeffrey Medeiros, ${ }^{*}$ Yong Li, Lan V. Pham, ${ }^{*}$ and Ken H. Young ${ }^{\star \S \S \S}$

From the Departments of Hematopathology* and Bioinformatics and Computational Biology, ${ }^{\ddagger}$ The University of Texas MD Anderson Cancer Center, Houston, Texas; the Department of Pathology, ${ }^{\dagger}$ Shanxi Cancer Hospital, Shanxi, China; the Department of Pathology, ${ }^{\S}$ University Hospital, Basel, Switzerland; the Department of Hematology, "San Bortolo Hospital, Vicenza, Italy; the Department of Pathology, "Hospital Universitario Marques de Valdecilla, Santander, Spain; the Department of Hematology, ${ }^{* *}$ Aalborg University Hospital, Aalborg, Denmark; the Department of Pathology, ${ }^{\dagger \dagger}$ Weill Medical College of Cornell University, New York, New York; the Department of Pathology and Cell Biology New York Presbyterian Hospital, New York, New York; the Department of Pathology, ${ }^{\S \S}$ Cleveland Clinic, Cleveland, Ohio; the Department of Pathology, ${ }^{\text {ब9 }}$ Radboud University Nijmegen Medical Centre, Nijmegen, the Netherlands; the San Raffaele H. Scientific Institute, III Milan, Italy; the Department of Pathology, *** National University Hospital, Singapore; the Department of Pathology, ${ }^{\dagger \dagger}$ Odense University Hospital, Odense, Denmark; the Department of Cancer Biology, ${ }^{\ddagger \ddagger}$ Cleveland Clinic, Lerner Research Institute, Cleveland, Ohio; and the University of Texas School of Medicine, ${ }^{\S \S \S}$ Graduate School of Biomedical Sciences, Houston, Texas

\author{
Accepted for publication \\ April 6, 2017. \\ Address correspondence to Ken \\ H. Young, M.D., Ph.D., \\ Department of Hematopathol- \\ ogy, The University of Texas \\ MD Anderson Cancer Center, \\ 1515 Holcombe Blvd., Hous- \\ ton, TX 77030-4009. E-mail: \\ khyoung@mdanderson.org.
}

AKT signaling is important for proliferation and survival of tumor cells. The clinical significance of AKT activation in diffuse large B-cell lymphoma (DLBCL) is not well analyzed. Here, we assessed expression of phosphorylated AKT ( $p$-AKT) in 522 DLBCL patients. We found that high levels of $p$-AKT nuclear expression, observed in $24.3 \%$ of the study cohort, were associated with significantly worse progressionfree survival and Myc and Bcl-2 overexpression. However, multivariate analysis indicated that AKT hyperactivation was not an independent factor. miRNA profiling analysis demonstrated that 63 miRNAs directly or indirectly related to the phosphatidylinositol 3-kinase/AKT/mechanistic target of rapamycin pathway were differentially expressed between DLBCLs with high and low p-AKT nuclear expression. We further targeted AKT signaling using a highly selective AKT inhibitor MK-2206 in 26 representative DLBCL cell lines and delineated signaling alterations using a reverse-phase protein array. MK-2206 treatment inhibited lymphoma cell viability, and MK-2206 sensitivity correlated with AKT activation status in DLBCL cells. On MK-2206 treatment, p-AKT levels and downstream targets of AKT signaling were significantly decreased, likely because of the decreased feedback repression; Rictor and phosphatidylinositol 3-kinase expression and other compensatory pathways were also induced. This study demonstrates the clinical and therapeutic implications of AKT hyperactivation in DLBCL and suggests that AKT inhibitors need to be combined with other targeted agents for DLBCL to achieve optimal clinical efficacy. (Am J Pathol 2017, 187: 1700-1716; http://dx.doi.org/10.1016/j.ajpath.2017.04.009)
Supported by NIH/National Cancer Institute grants R01CA138688 (Y.L. and K.H.Y.), 1RC1CA146299, P50CA136411, and P50CA142509, and the MD Anderson Cancer Center Support grant CA016672. J.W. is the recipient of senior professorship award. K.H.Y. is supported by The University of Texas MD Anderson Cancer Center Institutional Research and Development Fund, an Institutional Research Grant Award, an MD Anderson Cancer Center Lymphoma Specialized Programs on Research Excellence
(SPORE) Research Development Program Award, an MD Anderson Cancer Center Myeloma SPORE Research Development Program Award, and an MD Anderson Myeloma SPORE Research Developmental Program Award and the University Cancer Foundation through the Sister institution network Fund at The University of Texas MD Anderson Cancer Center.

J.W., Z.Y.X.-M., K.J.J., and Q.S. contributed equally to this work.

Disclosures: None declared. 
Diffuse large B-cell lymphoma (DLBCL) is the most common type of B-cell lymphoma. Patients with DLBCL have highly variable clinical presentations and outcomes, most likely explained by activation of a wide variety of oncogenic pathways. ${ }^{1,2}$ On the basis of gene expression profiling (GEP) or surrogate immunohistochemistry algorithms, most cases of DLBCL can be classified into two major cell-of-origin subtypes: prognostically favorable germinal center B-cell-like (GCB) and the prognostically unfavorable activated B-cell-like (ABC). ${ }^{1,3,4}$ However, even within these two groups, there is much prognostic and molecular heterogeneity.

The serine threonine protein kinase AKT (alias protein kinase B) plays an important role in cell growth and survival in many cancers. AKT has three isoforms (AKT1, AKT2, and AKT3) encoded by three different genes with different expression patterns. ${ }^{5,6}$ During activation, AKT is recruited to the cell membrane by the binding of phosphatidylinositoltriphosphate to its pleckstrin homology $(\mathrm{PH})$ domain [a process facilitated by phosphatidylinositol 3-kinase (PI3K) and negatively regulated by phosphatase and tensin homo$\log (\mathrm{PTEN})]{ }^{7}$ resulting in a conformational change that facilitates phosphorylation (activation) at the $\mathrm{Thr}^{308}$ residue by PDK1 and at the $\mathrm{Ser}^{473}$ residue by mechanistic target of rapamycin complex 2 [mTORC2; comprising mTOR, Rictor, target of rapamycin complex subunit LST8 (mLST8), and mSin 1$].{ }^{6,8}$ Phosphorylations at $\mathrm{Ser}^{473}$ and $\mathrm{Thr}^{308}$ are regulated independently, and their interactions and importance are controversial. ${ }^{8-10}$ Activated AKT translocates to the nucleus and phosphorylates many targets, leading to inhibition of tuberous sclerosis complex 2 (TSC2), glycogen synthase kinase $3 \beta$ (GSK-3b), Bcl-2-associated death promotor (BAD), Bcl-2-like protein 11 (Bim), and Forkhead box (FOXO) proteins and activation of mTORC1 [comprising mTOR, Raptor, mLST8, and proline-risk Akt substrate of $40 \mathrm{kDa}$ (PRAS40), ribosomal protein S6 kinase (S6K), and X-linked inhibitor of apoptosis protein (XIAP)]; these changes in turn result in protein synthesis, cell cycle progression, and suppression of apoptosis. ${ }^{5,8}$ The proproliferation function of AKT1 is important for the oncogenic transformation of epithelial tumors by Ras and Myc overexpression, which depends on mTORC1 but is independent of p53 inactivation and the antiapoptotic function of AKT in one previous study. ${ }^{11}$ After tumor onset, AKT1 ablation and pharmacologic inhibition of AKT in vivo resulted in regression of thymic lymphoma by modulating Skp2 activities in the cell cycle (mediated by p27) and apoptosis (mediated by FASL/FAS). ${ }^{12}$

A number of negative feedback mechanisms, including those from S6K and PRAS40, exist in the PI3K/AKT/mTOR pathway. mTORC1-inhibitor treatment results in enhanced mTORC2 activity and AKT-Ser ${ }^{473}$ phosphorylation owing to a decrease in feedback repression. Similarly, after PI3K inhibition or dual $\mathrm{PI} 3 \mathrm{~K} / \mathrm{mTOR}$ inhibition, cancer cells compensate by up-regulating genes involved in DNA damage and expression and phosphorylation of several growth factor receptor tyrosine kinases. ${ }^{5,8,9,13}$ The energy charge (ATP/AMP ratio) of cells reflecting nutrient and stress status may play a critical role in regulating the PI3K/AKT/mTOR axis. ${ }^{10}$ It has been suggested that targeting AKT instead of downstream mTORC1 may avoid the antiapoptotic effect aside proliferation inhibition. ${ }^{11} \mathrm{~A}$ highly selective and potent allosteric pan-AKT inhibitor, MK-2206, induces regression of thymic lymphoma, simulating p53 restoration, even though these tumors do not have AKT hyperactivation. ${ }^{12}$ MK-2206 can effectively block AKT signaling but has limited antitumor activity when used as a single agent in phase $1 / 2$ clinical trials designed for patients with solid tumors. ${ }^{6,14,15}$ In clinical trials for patients with acute myeloid leukemia, MK-2206 demonstrated insufficient clinical antileukemic activity and resulted in only modest inhibition of AKT signaling at maximum tolerated doses. ${ }^{16}$ Dual inhibition of AKT and mTOR resulted in synergistic antilymphoma cytotoxicity in DLBCL cell lines. ${ }^{17}$

It has been shown that overexpression of phosphorylated AKT (p-AKT) is associated with poor prognosis in patients with a number of solid tumors ${ }^{18,19}$ and some hematologic malignancies, ${ }^{20,21}$ including DLBCL. ${ }^{22-24}$ In the present study we assessed p-AKT ( $\operatorname{Ser}^{473}$ ) expression and AKTl mutation status and evaluated their prognostic importance in a large cohort of patients with de novo DLBCL treated with R-CHOP (rituximab plus cyclophosphamide, doxorubicin, vincristine, and prednisone). We also correlated p-AKT with expression of upstream and downstream biomarkers and analyzed the associated gene and miRNA expression profiles. Moreover, we evaluated the cytotoxic effects of MK2206 in 26 human DLBCL cell lines and comprehensively analyzed the altered expression and post-translational modifications of key signaling proteins on MK-2206 treatment in two representative DLBCL cell lines.

\section{Materials and Methods}

\section{Patients}

The study cohort, assembled as a part of the International DLBCL Consortium Program study, consisted of 522 patients with de novo DLBCL treated with R-CHOP with a median follow-up interval of 56 months. The study was approved by the Institutional Review Board of The University of Texas MD Anderson Cancer Center (MD Anderson). Cell-of-origin classification was mainly determined by GEP (https://www.ncbi.nlm.nih.gov/geo; accession number GSE31312) $(n=405)$ in combination with immunohistochemical algorithms $(n=110)$.

\section{Immunohistochemical Analysis}

Immunohistochemistry analysis was performed on formalinfixed, paraffin-embedded tissue microarrays to assess the expression of phosphorylated AKT using a p-AKT $\left(\mathrm{Ser}^{473}\right)$ antibody (LP18; Leica, Vista, CA), IL-6 (Novus 
Biologicals, Littleton, CO), PI3K (610046; BD Laboratories, San Jose, CA), and other biomarkers on tissue microarrays as previously described. ${ }^{4,25-31}$ Antigen expression was scored in 5\% increments by assessing the percentage of immunoreactive tumor cells independently by four senior experienced pathologists (K.J.J., Q.S., S.W., and K.H.Y.) with $99 \%$ consensus. Discordant cases were resolved by discussion under a multiheaded microscope.

\section{AKT1 Sequencing}

The coding region of AKTl (1443 bp; https://www.ncbi.nlm. nih.gov/genbank; GenBank accession number CCDS9994.1) was sequenced using a Sanger sequencing-based method by Polymorphic DNA Technologies Inc. (Alameda, CA). Single nucleotide polymorphisms documented by the dbSNP database have been excluded.

Methods for $B C L 2, B C L 6$, and $M Y C$ gene rearrangement analysis, TP53 sequencing, and GEP analysis were described previously. ${ }^{32,33}$

\section{GEP and miRNA Profiling Analysis}

Total RNA was extracted from formalin-fixed, paraffinembedded tissue samples and subjected to GEP analysis. The CEL files are deposited in the National Center for Biotechnology Information Gene Expression Omnibus repository (https:// www.ncbi.nlm.nih.gov/geo; accession number GSE31312). Normalized microarray data were analyzed for differential expression between subgroups. Univariate analysis was performed to identify differentially expressed genes using the $t$-test. The $P$ values obtained by multiple $t$-tests were corrected for false discovery rate using the beta-uniform mixture method.

miRNA profiling was performed using formalin-fixed, paraffin-embedded tissue sections by HTG Molecular Diagnostics Inc. (Tucson, AZ). miRNAs related to the PI3K/ AKT/mTOR pathway according to the literature or TargetScan were selected. Expression levels of miRNAs were compared using the unpaired $t$-test (two-tailed) and visualized by the heatmap.

\section{Cell Lines and the AKT Inhibitor Used in Cell Line Study}

DLBCL cell lines MS, DS, DBr, JM (McA), FN, EJ, HF, $\mathrm{HB}, \mathrm{MZ}, \mathrm{LR}, \mathrm{CJ}, \mathrm{LP}, \mathrm{WP}$, and RC were established at MD Anderson and were characterized and described previously. ${ }^{31,34}$ The Pfeifer DLBCL cell line was purchased from ATCC (Manassas, VA). The DLBCL cell lines U-2932, OCI-LY19, DOHH2, Toledo, SUDHL-4, SUDHL-10, HBL-1, TMD-8, HT, OCI-LY10, and OCI-LY3 were obtained from outside sources. All cell lines were routinely tested for Mycoplasma using a Myco Tect kit (Invitrogen, Carlsbad, CA) and were validated by short tandem repeat DNA fingerprinting at the Characterized Cell Line Core Facility at The University of Texas MD Anderson Cancer Center. Stocks of authenticated cell lines were stored in liquid nitrogen for future use, and all cell lines used in the studies described here were from these authenticated stocks.

AKT inhibitor MK-2206 (Selleck Chemicals, Houston, TX) were dissolved in dimethyl sulfoxide (Fisher Scientific, Hampton, NH) to $100 \mathrm{mmol} / \mathrm{L}$ and $20 \mathrm{mmol} / \mathrm{L}$ stock solution, respectively, and diluted with culture medium when use.

\section{Cell Culture and Cell Proliferation Assay}

DLBCL cells were cultured at $37^{\circ} \mathrm{C}$ in a $5 \% \mathrm{CO}_{2}$ atmosphere in RPMI-1640 medium (Gibco, ThermoFisher Scientific, Waltham, MA) supplemented with $15 \%$ fetal bovine serum (Gibco), $100 \mathrm{U} / \mathrm{mL}$ penicillin $\mathrm{G}$, and $100 \mathrm{mg} / \mathrm{mL}$ streptomycin (CellGro).

Briefly, cells were seeded into 96-well plates at 50,000 cells per well with varying concentrations of MK-2206 added to the wells. The total volume for each well is $200 \mu \mathrm{L}$. Dimethyl sulfoxide was used as a solvent control. The optical density was measured at $450 \mathrm{~nm}$ on an enzyme-linked immunosorbent assay reader using CellTiter $96 \mathrm{AQ}_{\text {ueous }}$ nonradioactive cell proliferation assay with the Bio-Rad (Hercules, CA) benchmark microplate reader after 48 hours of incubation. Each assay was performed in triplicate, and the mean values were obtained from the results of three independent assays.

\section{Western Blot Analysis}

Protein was extracted using radioimmunoprecipitation assay lysis buffer with phosphatase inhibitor cocktail and protease inhibitor cocktail. Protein concentrations of the lysates were determined using Bio-Rad protein assay reagent kit (Bio-Rad). Equal amounts of total protein $(50 \mu \mathrm{g})$ were resolved by SDSPAGE and transferred to a polyvinylidene fluoride membrane using the semidry transfer method. Membranes were blocked with blocking buffer at room temperature for 20 minutes and then incubated with the primary antibodies [AKT (pan) no. 4691 and anti-pAKT (Ser ${ }^{47}$ ) antibody no. 9271 (Cell Signaling, Danvers, MA); Total AKT, dilution 1:1000; pAKT, dilution 1:500; actin, dilution 1:10,000 (Sigma-Aldrich, St. Louis, MO)] overnight at $4^{\circ} \mathrm{C}$. After washing three times with tris-buffered saline and Tween 20 buffer (Bio-Rad), membranes were incubated with secondary antibody (goat antirabbit, dilution 1:2000; goat anti-mouse, dilution 1:10,000) at room temperature for 1 hour, followed by extensive washing with tris-buffered saline and Tween 20 buffer. Bands were detected using the HyGLO Quick Spray enhanced chemiluminescence system (Denville Scientific, Holliston, MA).

\section{RPPA Analysis}

Protein lysates extracted from DLBCL cell lines were analyzed using reverse-phase protein array (RPPA) at MD Anderson Functional Proteomics RPPA Core. Briefly, protein lysate was collected from control and MK-2206-treated DLBCL cell cultures after 24 and 48 hours. For total protein lysate preparation, media were removed, and cells were washed twice with 
ice-cold phosphate-buffered saline containing Complete protease and PhosSTOPphosphatase inhibitor cocktail tablets (Roche Applied Science, Mannheim, Germany) and $1 \mathrm{mmol} / \mathrm{L}$ $\mathrm{Na}_{3} \mathrm{VO}_{4}$. Lysis buffer (1\% Triton X-100, $50 \mathrm{mmol} / \mathrm{L}$ HEPES, $\mathrm{pH} 7.4,150 \mathrm{mmol} / \mathrm{L} \mathrm{NaCl}, 1.5 \mathrm{mmol} / \mathrm{L} \mathrm{MgCl} 2,1 \mathrm{mmol} / \mathrm{L}$ EGTA, $100 \mathrm{mmol} / \mathrm{L} \mathrm{NaF}, 10 \mathrm{mmol} / \mathrm{L} \mathrm{NaPPi}, 10 \%$ glycerol, 1 $\mathrm{mmol} / \mathrm{L}$ phenylmethylsulfonyl fluoride, $1 \mathrm{mmol} / \mathrm{L} \mathrm{Na}_{3} \mathrm{VO}_{4}$, and $10 \mu \mathrm{g} / \mathrm{mL}$ aprotinin) was added. Samples were mixed by vortex frequently on ice and then centrifuged. Protein lysates were adjusted to a $1 \mu \mathrm{g} / \mu \mathrm{L}$ concentration, and a serial dilution of 5 concentrations was printed, with $10 \%$ of the samples replicated for quality control (2470 Arrayer; Aushon Biosystems, Billerica, MA) on nitrocellulose-coated slides (Grace Bio-Labs, Bend, OR). Immunostaining was performed using a DakoCytomation-catalyzed system (Dako, Carpinteria, CA) and diaminobenzidine colorimetric reaction. Slides were scanned on a flatbed scanner to produce 16-bit tiff images. Spot intensities were analyzed and quantified using Array-Pro Analyzer to generate spot signal intensities. Relative protein levels for each sample were determined by interpolation of each dilution curve from the standard curve constructed by a script in R-written Bioinformatics. All of the data points were normalized for protein loading and transformed to linear values that can be used for bar graphs. Normalized linear value was transformed to $\log 2$ value, and then median-centered for hierarchical cluster analysis and for heatmap generation. The heatmap was generated in Cluster 3.0 (University of Tokyo, Human Genome Center, Tokyo, Japan; http://cluster2. software.informer.com/3.0, last accessed February 07, 2017) as a hierarchical cluster using Pearson Correlation and a center metric. The resulting heatmap was visualized in Treeview version 3.0 (http://jtreeview.sourceforge.net, last accessed February 07, 2017) and presented as a high resolution .bmp format. Totally, 285 unique antibodies and four secondary antibody-negative controls were analyzed.

\section{Statistical Analysis}

Clinicopathologic and molecular features were compared using the Fisher exact or $\chi^{2}$ test. Overall survival (OS) and progression-free survival (PFS) were analyzed using the Kaplan-Meier method, and differences between subgroups were compared using the log-rank test. Multivariate analysis was performed using the Cox proportional hazards regression model. The GraphPad Prism 6 (GraphPad Software, San Diego, CA) and SPSS software version 19.0 (IBM Corporation, Armonk, NY) were used. All differences with $P \leq 0.05$ were considered statistically significant.

\section{Results}

p-AKT $\left(\operatorname{Ser}^{473}\right)$ Is Predominantly Expressed in the Nucleus in the DLBCL Samples

Nuclear p-AKT expression (variable levels, 5\% to 100\%) was found in 371 of 522 DLBCL cases (71\%) assessed by immunohistochemistry. Figure 1A shows representative p-AKT positive staining, and Figure 1B shows the histogram for $\mathrm{p}$-AKT nuclear expression in this cohort. The mean level of nuclear p-AKT expression in the studied patients was $33.3 \%$. No significant difference was found in p-AKT levels between GCB and ABC subtypes (Figure 1C).

Cytoplasmic p-AKT expression was rare and was detected in only 10 DLBCL tumors (levels, 3\% to 100\%), including eight cases that also had $100 \%$ p-AKT ${ }^{+}$nuclear expression and two cases without p-AKT nuclear expression.

\section{p-AKT Nuclear Overexpression Is Associated with Poorer Prognosis in DLBCL Patients}

We used X tile software version 3.6.1 (Yale School of Medicine, New Haven, CT) to determine the immunohistochemical cutoff for p-AKT overexpression associated with significant prognostic impact with maximum specificity and sensitivity. With the use of this method, the cutoff for pAKT nuclear overexpression (p-AKT ${ }^{\text {high }}$ ) was set at $\geq 70 \%$; 127 of 522 patients $(24.3 \%)$ had p-AKT ${ }^{\text {high }}$ DLBCL. These patients had significantly worse PFS $(P=0.0027)$ and OS $(P=0.047)$ than other patients with $\mathrm{p}-\mathrm{AKT}^{\mathrm{low}}$ DLBCL (Figure 1D). The 5-year PFS rate was $45.8 \%$ for patients with p-AKT ${ }^{\text {high }}$ DLBCL and $61 \%$ for patients with $\mathrm{p}^{-\mathrm{AKT}^{\text {low }}}$ DLBCL (hazard ratio $=1.54 ; 95 \% \mathrm{CI}$, 1.19-2.25). The frequencies of $\mathrm{p}-\mathrm{AKT}^{\text {high }}$ were similar among the GCB and ABC subtypes. In GCB-DLBCL, p-AKT overexpression was associated with significantly lower PFS $(P=0.015)$ but not OS $(P=0.42)$ rate. In ABC-DLBCL, the unfavorable effects associated with p-AKT ${ }^{\text {high }}$ did not reach statistical significance (OS, $P=0.10$; PFS, $P=0.14$ ).

\section{p-AKT Overexpression Is Associated with Myc and Bcl-2 Overexpression}

We compared the clinical and molecular features of $\mathrm{p}-\mathrm{AKT}^{\text {high }}$ patients with p-AKT ${ }^{\text {low }}$ patients (Tables 1 and 2). ${ }^{4,25-32}$ Consistent with the role of PI3K in AKT activation, the $\mathrm{p}-\mathrm{AKT}^{\text {high }}$ group had a significantly higher mean level of PI3K expression than the p-AKT ${ }^{\text {low }}$ group (Figure $1 \mathrm{E}$ ). In addition, the $\mathrm{p}-\mathrm{AKT}^{\text {high }}$ group had higher frequencies of $\mathrm{IL}_{-} 6^{+}, \mathrm{Myc}^{\text {high }}, \mathrm{Bcl}-2^{\text {high }}, \mathrm{p}-\mathrm{STAT} 3^{\text {high }}$, FOXP $1^{\text {high }}$, wild-type-p $53^{\text {high }}$, and BLIMP- $1^{+}$expression, and lower frequencies of TP53 mutations and nuclear expression of NF- $\mathrm{B}$ subunits $\mathrm{p} 50, \mathrm{p} 52$, and c-Rel (Table 2).

The positive correlations between $\mathrm{p}-\mathrm{AKT}^{\text {high }}$ and $\mathrm{Bcl}-$ $2^{\text {high }}$ expression and negative NF- $\mathrm{BB}$ (p50, p52, and c-Rel) nuclear expression were significant in both the GCB and $\mathrm{ABC}$ subsets. Myc ${ }^{\text {high }}$ was more frequent in $\mathrm{p}-\mathrm{AKT}^{\text {high }}$ patients with GCB-DLBCL, likely owing to the increased frequency of MYC translocations. The association of 
A

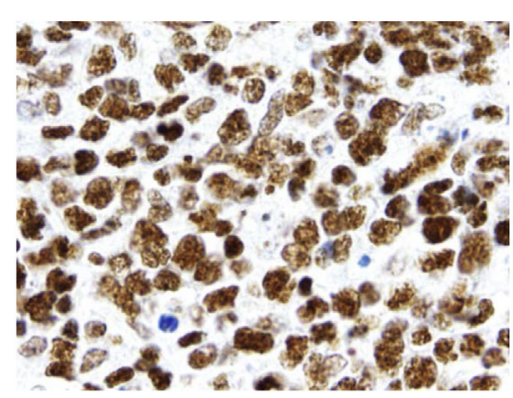

D

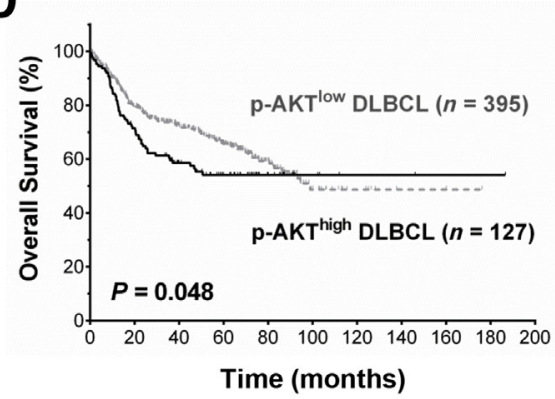

F

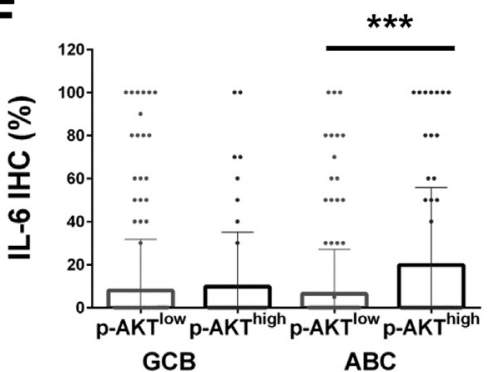

B
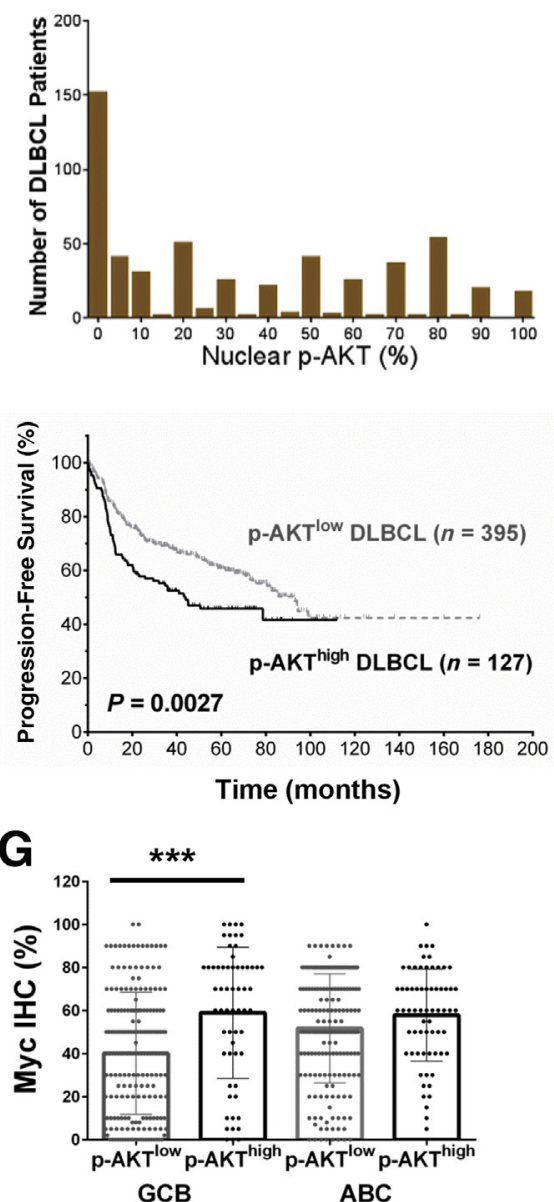

E
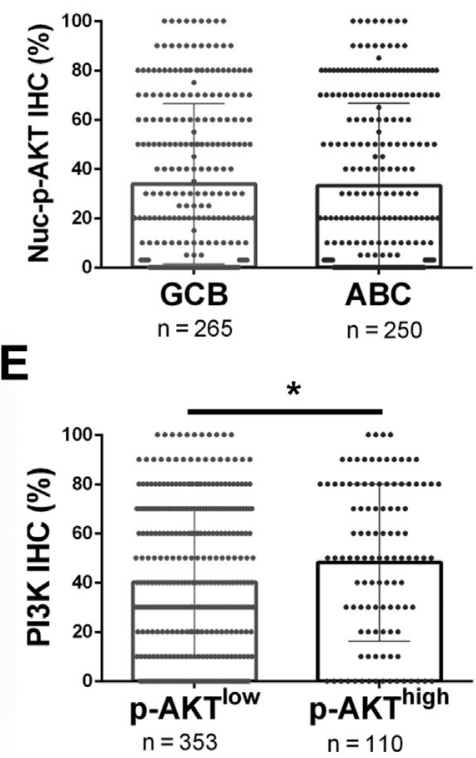

H

C

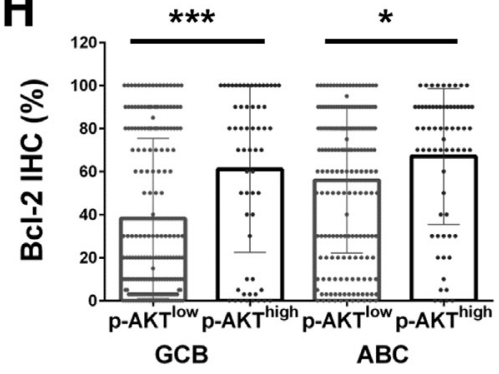

Figure 1 Expression and prognostic analysis of phosphorylated AKT (p-AKT) expression in diffuse large B-cell lymphoma (DLBCL). A: Representative immunohistochemistry (IHC) staining for p-AKT. B: Histogram of p-AKT immunohistochemistry scores in the DLBCL cohort. C: Scatter plot for nuclear p-AKT (Nuc-p-AKT) expression in DLBCL patients. The mean levels of Nuc-p-AKT expression in the germinal center B-cell-like (GCB) and activated Bcell-like (ABC) DLBCL subtypes are similar per IHC analysis. D: $p$-AKT ${ }^{\text {high }}$ expression ( $\geq 70 \%$ of tumor cells showing positive $p$-AKT nuclear staining) is associated with significantly poorer overall survival $(O S)$ and progression-free survival in patients with DLBCL. E: Scatter plot for phosphatidylinositol 3-kinase (PI3K) expression in DLBCL patients. The $p-A K T^{\text {high }}$ group has a significantly higher mean level of PI3K expression than the $p$-AKT ${ }^{\text {low }}$ group. F-H: Scatter plot for IL-6, Myc, and Bcl-2 expression by IHC in DLBCL patients. Compared with the $p-A K T^{\text {low }}$ group, the $p-A K T^{\text {high }}$ group has a significantly higher mean level of IL-6 expression in ABC-DLBCL, Myc expression in GCB-DLBCL, and Bcl-2 expression in both GCB- and ABC-DLBCL. Each dot in the scattered plots represents the expression level in one patient. ${ }^{*} P<0.05,{ }^{* *} P<0.001$. Original magnification, $\times 60$.

p-AKT ${ }^{\text {high }}$ with IL- 6 , p-STAT3 $^{\text {high }}$, and BLIMP-1 ${ }^{+}$ expression and the negative correlation with TP53 mutations were significant only in the $\mathrm{ABC}$ subtype (Table 2 and Figure 1, F-H).

To evaluate the contribution of Bcl-2, Myc, and p-STAT3 overexpression to the poorer survival associated with $\mathrm{p}$ $\mathrm{AKT}^{\text {high }}$ DLBCL, we compared the survival of $\mathrm{p}-\mathrm{AKT}^{\text {high }}$ and $\mathrm{p}-\mathrm{AKT}^{\text {low }}$ DLBCL patients with and without $\mathrm{Bcl}-2$, Myc, and p-STAT3 overexpression. We found no difference in survival between $\mathrm{p}-\mathrm{AKT}^{\mathrm{high}}$ and $\mathrm{p}-\mathrm{AKT}^{\text {low }}$ patients in the $\mathrm{Bcl}-2^{\text {high }}$, $\mathrm{Myc}^{\text {high }}, \mathrm{Myc}^{\text {high }} \mathrm{Bcl}-2^{\text {high }}$ (double-positive, DP), and p-STAT3 $3^{\text {high }}$ DLBCL subsets. However, within the $\mathrm{Bcl}-2^{\text {low }}, \mathrm{Myc}^{\text {low }}$, non-DP, and p-STAT3 ${ }^{\text {low }}$ subsets, p-AKT ${ }^{\text {high }}$ patients had significantly worse PFS than p-AKT ${ }^{\text {low }}$ patients (Figure 2). However, in these four subsets (ie, Bcl-2 ${ }^{\text {low }}, \mathrm{Myc}^{\text {low }}$, non-DP, and p-STAT3 ${ }^{\text {low }}$ ), the $\mathrm{p}-\mathrm{AKT} \mathrm{T}^{\text {high }}$ groups all had significantly higher mean levels of Myc expression than the $\mathrm{p}-\mathrm{AKT}^{\mathrm{low}}$ groups; in the $\mathrm{Myc}^{\text {low }}$, non-DP, and p-STAT3 ${ }^{\text {low }}$ subsets, the $\mathrm{p}-\mathrm{AKT}^{\text {high }}$ groups also had significantly higher mean expression levels of Bcl-2 (Figure 2).

Multivariate survival analysis for p-AKT overexpression with adjustment for clinical parameters resulted in a borderline $P$ value for adverse impact on PFS in the overall DLBCL cohort (Table 3). However, additional adjustment for $\mathrm{Myc} / \mathrm{Bcl}-2$ overexpression and TP53 mutation status showed that $\mathrm{p}-\mathrm{AKT}^{\text {high }}$ was not a significant independent prognostic factor in overall DLBCL (for OS, $P=0.64$; for PFS, $P=0.33$ ) or in the GCB- and ABC-DLBCL subgroups (data not shown). 
Table 1 Clinicopathologic Features of DLBCL Patients with High or Low p-AKT Expression

\begin{tabular}{|c|c|c|c|c|c|c|c|c|c|}
\hline \multirow[b]{2}{*}{ Variable } & \multicolumn{3}{|l|}{ DLBCL } & \multicolumn{3}{|l|}{ GCB-DLBCL } & \multicolumn{3}{|l|}{$A B C-D L B C L$} \\
\hline & $\begin{array}{l}\text { p-AKT }{ }^{\text {high }} \\
(n=127)\end{array}$ & $\begin{array}{l}\text { p-AKT } \\
(n=395)\end{array}$ & $P$ & $\begin{array}{l}\text { p-AKT }{ }^{\text {high }} \\
(n=61)\end{array}$ & $\begin{array}{l}\text { p-AKT }{ }^{\text {low }} \\
(n=204)\end{array}$ & $P$ & $\begin{array}{l}\text { p-AKT } T^{\text {high }} \\
(n=66)\end{array}$ & $\begin{array}{l}\text { p-AKT }{ }^{\text {low }} \\
(n=184)\end{array}$ & $P$ \\
\hline$<60$ & $61(48.0)$ & $163(41.3)$ & 0.18 & $35(57.4)$ & $99(48.5)$ & 0.25 & $26(39.4)$ & $59(32.1)$ & 0.29 \\
\hline$\geq 60$ & $66(52.0)$ & $232(58.7)$ & & $26(42.6)$ & $105(51.5)$ & & $40(60.6)$ & $125(67.9)$ & \\
\hline \multicolumn{10}{|l|}{ Sex } \\
\hline \multicolumn{10}{|l|}{ Stage } \\
\hline I/II & $51(42.1)$ & $186(48.4)$ & 0.25 & $27(47.4)$ & $111(56.1)$ & 0.29 & $24(37.5)$ & $70(39.1)$ & 0.88 \\
\hline III/IV & $70(57.9)$ & $198(51.6)$ & & $30(52.6)$ & $87(43.9)$ & & $40(62.5)$ & $109(60.9)$ & \\
\hline \multicolumn{10}{|l|}{ B-symptoms } \\
\hline Absence & $75(62.0)$ & $244(65.2)$ & 0.51 & $43(75.4)$ & $130(67.7)$ & 0.33 & $32(50.0)$ & $109(62.3)$ & 0.1 \\
\hline \multicolumn{10}{|c|}{ Number of extranodal sites } \\
\hline $0-1$ & $84(70.0)$ & $298(78.2)$ & 0.085 & $42(73.7)$ & $154(79.4)$ & 0.37 & $42(66.7)$ & $138(76.7)$ & 0.13 \\
\hline$\geq 2$ & $36(30.0)$ & $83(21.8)$ & & $15(26.3)$ & $40(20.6)$ & & $21(33.3)$ & $42(23.3)$ & \\
\hline \multicolumn{10}{|l|}{ ECOG score } \\
\hline $0-1$ & $92(81.4)$ & $298(84.2)$ & 0.47 & $44(84.6)$ & $153(86.0)$ & 0.82 & $48(78.7)$ & $138(81.7)$ & 0.7 \\
\hline$\geq 2$ & $21(18.6)$ & $56(15.8)$ & & $8(15.4)$ & $25(14.0)$ & & $13(21.3)$ & $31(18.3)$ & \\
\hline \multicolumn{10}{|c|}{ Tumor size, $\mathrm{cm}$} \\
\hline$<5$ & $49(57.6)$ & $173(57.5)$ & 1.0 & $19(51.4)$ & $94(60.3)$ & 0.36 & $30(62.5)$ & $76(54.3)$ & 0.4 \\
\hline$\geq 5$ & $36(42.4)$ & $128(42.5)$ & & $18(48.6)$ & $62(39.7)$ & & $18(37.5)$ & $64(45.7)$ & \\
\hline \multicolumn{10}{|l|}{ IPI score } \\
\hline $0-2$ & $71(57.3)$ & $243(63.6)$ & 0.24 & $38(63.3)$ & $136(69.7)$ & 0.35 & $33(51.6)$ & $100(55.6)$ & 0.66 \\
\hline
\end{tabular}

Data are expressed as $n(\%)$ unless otherwise indicated. For therapy response, $P$ values were calculated as CR versus other responses. Percentages were calculated from the total number of patients whose data were available for the characteristic of interest. Not all patients had data available for every characteristic.

$A B C$, activated B-cell-like; CR, complete response; DLBCL, diffuse large B-cell lymphoma; ECOG, Eastern Cooperative Oncology Group; GCB, germinal center B-cell-like; IPI, international prognostic index; LDH, lactate dehydrogenase; $p$-AKT ${ }^{\text {high }}$, high levels $(\geq 70 \%)$ of phospho-AKT expression; $p$-AKT ${ }^{\text {low }}$, low levels $(<70 \%)$ of phospho-AKT expression; PD, progressive disease; PR, partial response; SD, stable disease.

\section{AKT1 and AKT2 mRNA Expression Correlates with Different Prognostic Effects}

The $\mathrm{p}-\mathrm{AKT}^{\text {high }}$ and $\mathrm{p}-\mathrm{AKT}^{\text {low }}$ groups did not show significant differences in $A K T 1 / 2$ mRNA levels $(P=0.56)$. In addition, we analyzed the prognostic effects associated with AKT1/2/3 mRNA expression. High levels of AKT1 mRNA were associated with significantly poorer survival (OS, $P=0.0032$; PFS, $P=0.0062$ ) in DLBCL patients overall and in the GCB and ABC subgroups. Similar prognostic effects of $A K T 3$ mRNA expression were observed but with nonsignificant $P$ values. In contrast, high $A K T 2$ mRNA levels were associated with better survival in DLBCL with borderline $P$ values (OS, $P=0.09$; PFS, $P=0.078$ ) (Figure 3).

\section{GEP Analysis}

To better understand the molecular mechanisms for AKT hyperactivation and its prognostic effect, we further compared the gene expression profiles of $\mathrm{p}-\mathrm{AKT}^{\text {high }}$ and p-AKT ${ }^{\text {low }}$ patients and found 29 transcripts differentially expressed with a false discovery rate $<0.01$ (Figure 4A) and 251 significant transcripts with a false discovery rate threshold of 0.05 . When GCB and $\mathrm{ABC}$ subtypes were analyzed separately, gene signatures were identified significantly only in GCB-DLBCL (174 transcripts with a false discovery rate $<0.05$ ) (Figure $4 \mathrm{~B}$ and Table 4 ). Many genes involved in immune responses $(C I S, I L 1 R 1, C 3, C 2$, CCL5, IFNGR1, CEBPD, HLA genes, and B2M), extracellular matrix, cell adhesion, collagen, cytoskeleton, and 
Table 2 Comparison of Molecular Features of DLBCL Patients with High or Low p-AKT Expression

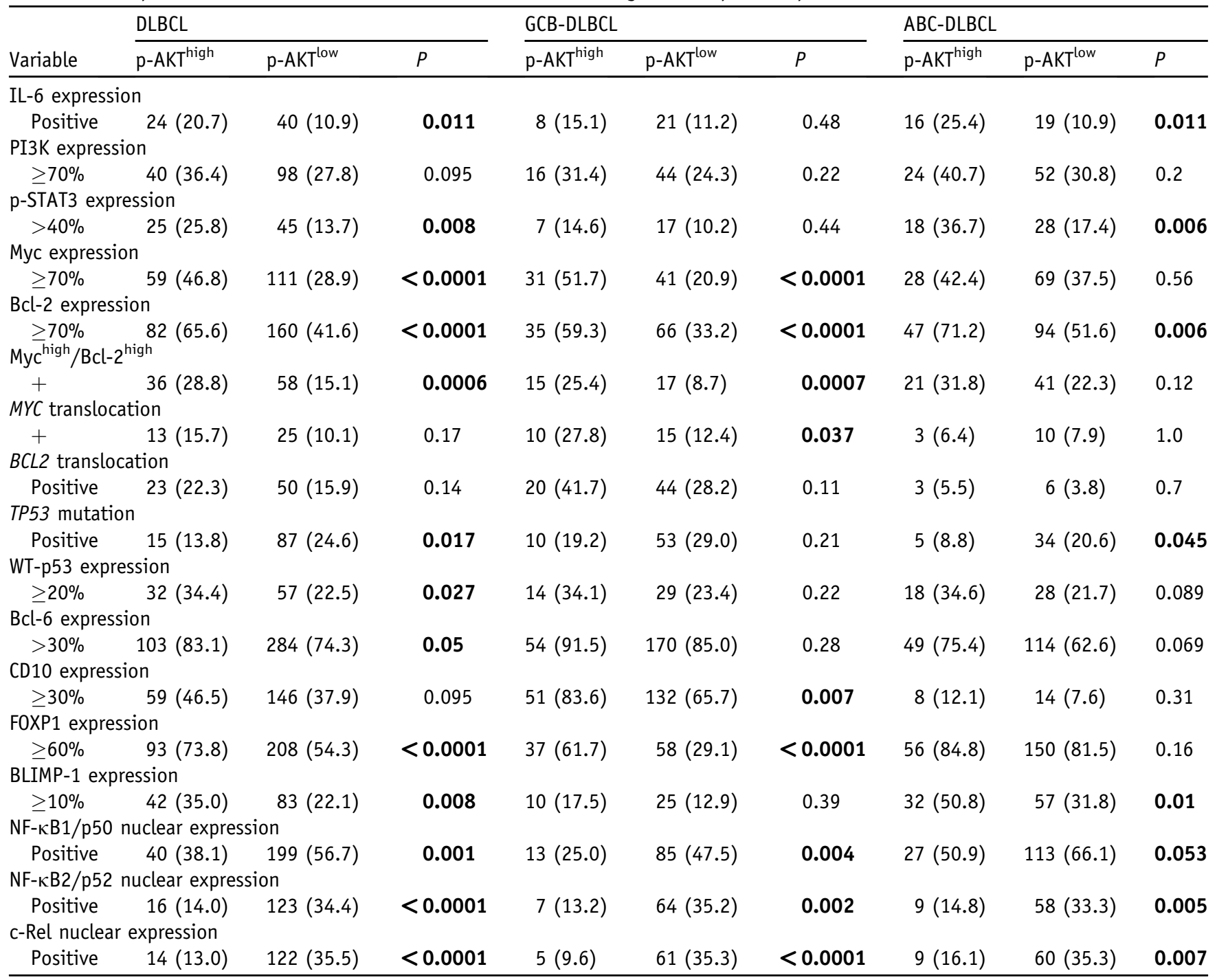

Data are expressed as $n(\%)$ unless otherwise indicated. Percentages were calculated as positive cases/total cases with results available. Bold indicates significant values.

ABC, activated B-cell-like; DLBCL, diffuse large B-cell lymphoma; GCB, germinal center B-cell-like; p-AKT ${ }^{\text {high }}$, high levels ( $\left.\geq 70 \%\right)$ of phospho-AKT expression; p-AKT ${ }^{\text {low }}$, low levels $(<70 \%)$ of phospho-AKT expression; PI3K, phosphatidylinositol 3-kinase; WT, wild-type.

metabolisms were down-regulated in $\mathrm{p}-\mathrm{AKT}^{\text {high }}$ patients. In contrast, $M D M 2$ and $M A P 2 K$ were up-regulated. When analyzing $P D-1 / P D-L 1 / L 2$ genes in particular, we found that $\mathrm{p}-\mathrm{AKT} \mathrm{T}^{\text {high }}$ correlated with $P D-L 2$ down-regulation in GCB-DLBCL (Figure 4C).

miRNAs May Play an Important Role in p-AKT Hyperactivation

In contrast to the lack of correlation between p-AKT and AKT1 mRNA levels, we found 63 miRNAs related to the $\mathrm{PI} 3 \mathrm{~K} / \mathrm{AKT} / \mathrm{mTOR}$ pathway that were significantly differentially expressed between the p-AKT ${ }^{\text {high }}$ and $\mathrm{p}-\mathrm{AKT}^{\text {low }}$ DLBCL groups (Figure 4D). For example, the mean expression levels of miR-22-3p, miR-23a-5p, let-7c-5p, let-7b-5p, miR-143-3p, miR-99a-5p, miR-125b-5p,
miR-125b-1-3p, miR-27a-5p, miR-320a/b/c/d/e, miR-204$3 \mathrm{p}$, and miR-425-3p (for all, $P<0.0001$ ), miR-29c-5p $(P=0.0001)$, miR-214-5p $(P=0.0005)$, miR-7-5p $(P=0.0008)$, and miR-222-5p $(P=0.0092)$ were significantly lower in the $\mathrm{p}-\mathrm{AKT}^{\text {high }}$ group, whereas the mean expression levels of miR-17-5p $(P<0.0001)$, miR20a-5p $(P=0.0018)$, and miR-20b-5p $(P=0.0038)$ were significantly higher in the $\mathrm{p}-\mathrm{AKT}^{\text {high }}$ group in the overall DLBCL cohort and in the GCB and ABC subgroups.

\section{AKT Mutation Appears to Have No Pathologic} Significance in DLBCL

We sequenced the $A K T 1$ genes in 192 DLBCL (103 GCB and $86 \mathrm{ABC}$ ) samples. Nonsynonymous $A K T 1$ mutations $(n=36)$ were detected in 32 of 192 samples $(16.7 \%)$, 
A
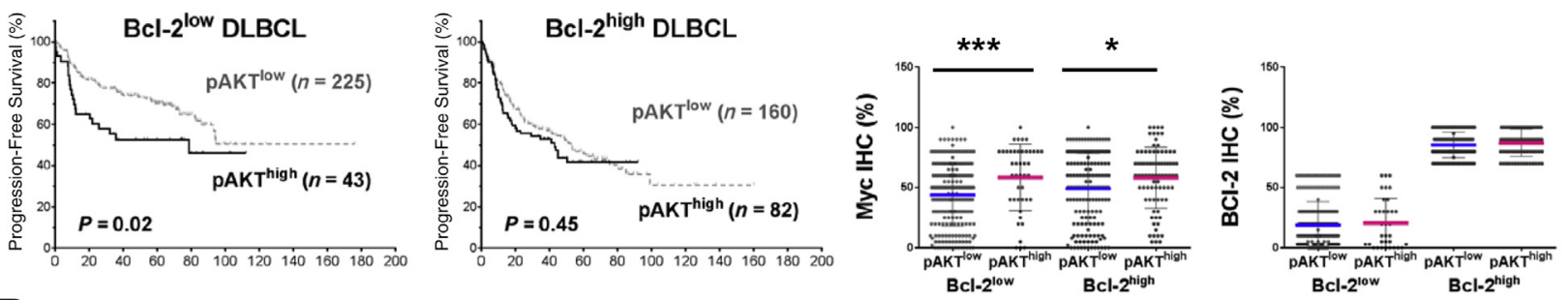

B
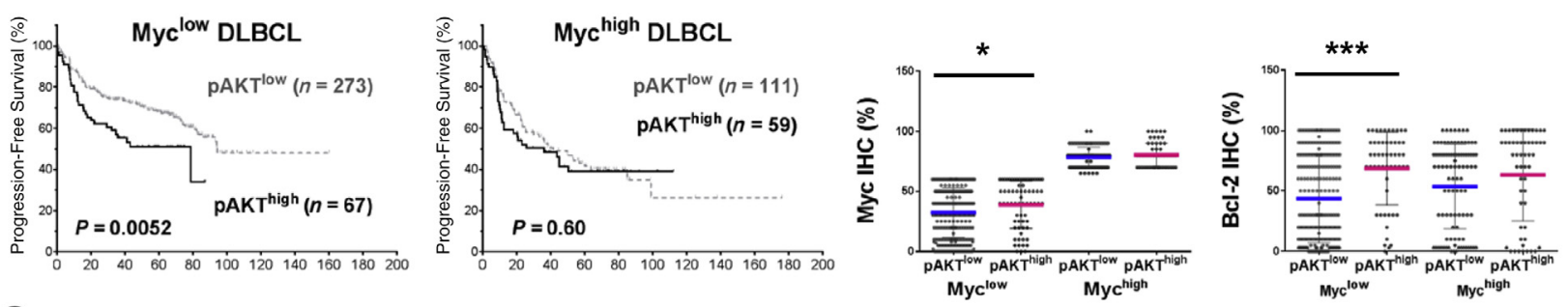

C
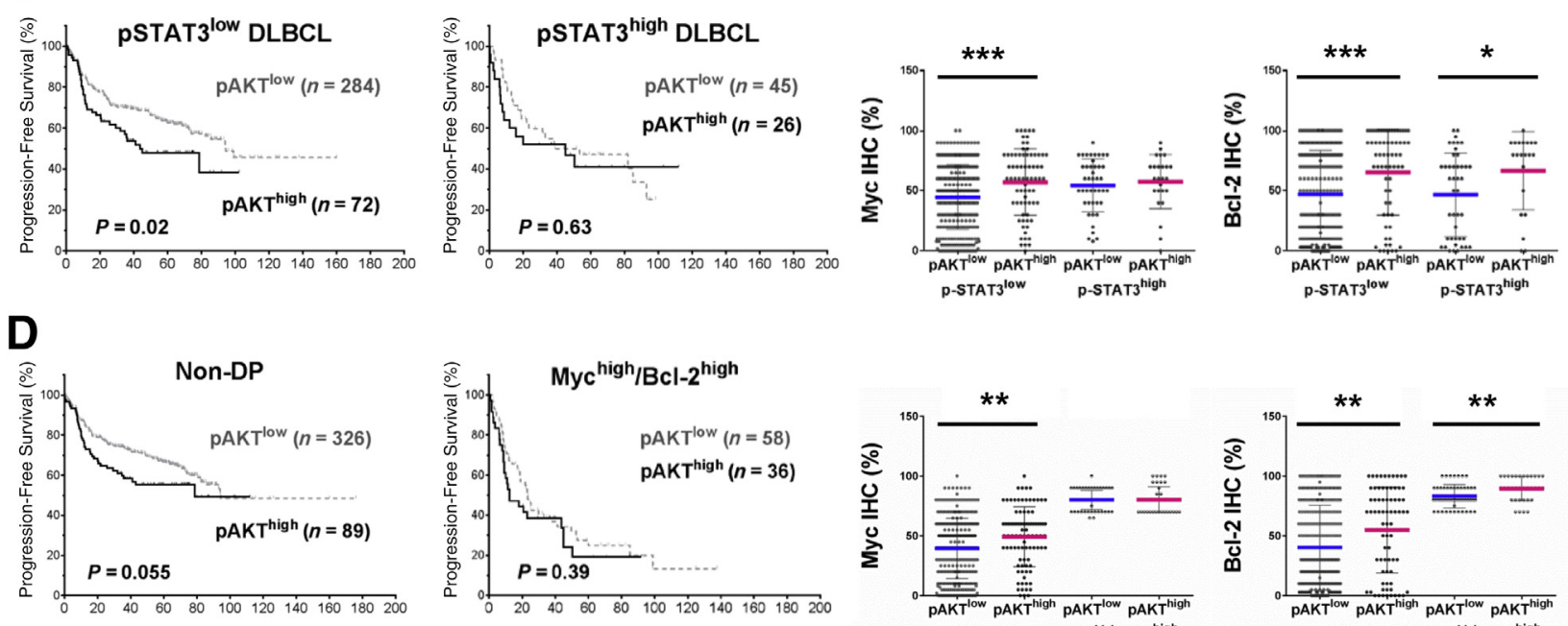

Months
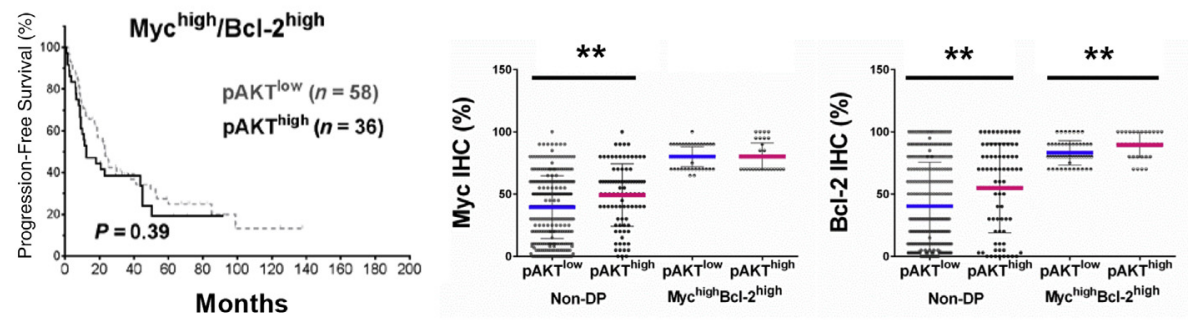

Figure 2 Prognostic and expression analysis of phosphorylated AKT (pAKT) overexpression (pAKT ${ }^{\text {high }}$ ) in diffuse large B-cell lymphoma (DLBCL) with and without Myc, Bcl-2, and phosphorylated STAT3 (pSTAT3) overexpression, as shown by the Kaplan-Meier curves and scatter plots. The cutoffs for Bcl-2 ${ }^{\text {high }}$, Myc $^{\text {high }}$, and PSTAT3 ${ }^{\text {high }}$ were $\geq 70 \%, \geq 70 \%$, and $\geq 50 \%$, respectively. A: In the Bcl- $2^{\text {low }}$ subset, but not Bcl- $2^{\text {high }}$ subset, pAKT ${ }^{\text {high }}$ is associated with significantly worse progression-free survival (PFS). However, in both $\mathrm{Bcl}-2^{\text {low }}$ and $\mathrm{Bcl}-2^{\text {high }}$ subsets, Myc expression is significantly higher in the pAKT $\mathrm{T}^{\text {high }}$ group than in the pAKT ${ }^{\text {low }}$ group. Within the $\mathrm{Bcl}-2^{\text {low }}$ and $\mathrm{Bcl}-2^{\text {high }}$ subsets, $\mathrm{Bcl}-2$ expression does not show much difference between the pAKT ${ }^{\text {high }}$ and pAKT $^{\text {low }}$ groups. B: In the Myc ${ }^{\text {low }}$, but not the Myc $\mathrm{Cigh}^{\text {high }}$ subset, pAKT ${ }^{\text {high }}$ is associated with significantly worse PFS. However, in the Myc ${ }^{\text {low }}$ subset, both Myc and Bcl-2 levels are significantly higher in the pAKT ${ }^{\text {high }}$ group than in the pAKT ${ }^{\text {low }}$ group. C: In the pSTAT3 ${ }^{\text {low }}$ subset, but not the pSTAT3 $3^{\text {high }}$ subset, pAKT ${ }^{\text {high }}$ is associated with significantly worse PFS. However, in the $\mathrm{pSTAT}^{\text {low }}$ subset, both Myc and Bcl-2 levels are significantly higher in the pAKT ${ }^{\text {high }}$ group than in the pAKT ${ }^{\text {low }}$ group. D: In the non - double-positive (DP) subset but not in the $\mathrm{Myc}^{\text {high }} / \mathrm{Bcl}^{-2^{\text {high }}}$ (DP) subset, $\mathrm{PAKT}^{\text {high }}$ is associated with significantly worse PFS. However, in the non-DP subset, both Myc and Bcl-2 levels are significantly higher in the AAKT $^{\text {high }}$ group than in the pAKT ${ }^{\text {low }}$ group. In the scatter plots, each dot represents the expression level in one patient. The mean expression levels in the $\mathrm{pAKT} \mathrm{T}^{\text {low }}$ group are indicated by blue lines; the mean expression levels in the pAKT ${ }^{\text {low }}$ group are indicated by pink lines. ${ }^{*} P<0.05,{ }^{*} P<0.01,{ }^{* *} P<0.001$.

including eight mutations in the $\mathrm{PH}$ domain, 22 in the catalytic (protein kinase) domain, and five in the C-terminal extension domain (Figure 5A). No correlation was observed between $A K T 1$ mutation status and p-AKT expression, and no significant prognostic difference was observed between patients with $A K T 1$ mutations (overall or domain-specific mutations) and those without, either in overall DLBCL (OS, $P=0.82$; PFS, $P=0.94$ ) or within the GCB and $\mathrm{ABC}$ subsets. Among patients with p-AKT overexpression, the four cases with mutated AKT appeared to have poorer OS and PFS than cases with wild-type AKT, especially in cases of GCB-DLBCL (one had mutation in the PH domain, and two had mutations in the catalytic domain) (Figure 5, B and $\mathrm{C}$ ). However, these four mutated $\mathrm{p}-\mathrm{AKT}^{\text {high }}$ cases also had Myc and Bcl-2 overexpression. For the three GCBDLBCL cases, one had MYC translocation, one had BCL2 translocation, and one had both TP53 deletion and BCL6 translocation. 
Table 3 Multivariate Analysis for Nuclear p-AKT Overexpression in DLBCL, GCB-DLBCL, and ABC-DLBCL

\begin{tabular}{|c|c|c|c|c|}
\hline \multirow[b]{2}{*}{ Variable } & \multicolumn{2}{|l|}{ Overall survival } & \multicolumn{2}{|c|}{ Progression-free survival } \\
\hline & $\mathrm{HR}(95 \% \mathrm{CI})$ & $P$ & $\mathrm{HR}(95 \% \mathrm{CI})$ & $P$ \\
\hline \multicolumn{5}{|l|}{ DLBCL } \\
\hline Female sex & $1.00(0.71-1.40)$ & 1.00 & $0.98(0.71-1.35)$ & 0.89 \\
\hline Tumor size $>5 \mathrm{~cm}$ & $1.33(0.96-1.86)$ & 0.09 & $1.27(0.93-1.75)$ & 0.13 \\
\hline B-symptoms & $1.37(0.97-1.94)$ & 0.075 & $1.37(0.99-1.91)$ & 0.061 \\
\hline IPI >2 & $3.51(2.08-5.92)$ & $<0.001$ & $3.40(2.09-5.55)$ & $<0.001$ \\
\hline Female sex & $0.96(0.57-1.61)$ & 0.87 & $1.04(0.64-1.685)$ & 0.88 \\
\hline Tumor size $>5 \mathrm{~cm}$ & $1.50(0.90-2.50)$ & 0.12 & $1.45(0.90-2.34)$ & 0.13 \\
\hline B-symptoms & $1.38(0.82-2.33)$ & 0.23 & $1.27(0.77-2.10)$ & 0.35 \\
\hline Nuclear p-AKT ${ }^{\text {high }}$ & $1.15(0.61-2.17)$ & 0.67 & $1.39(0.78-2.48)$ & 0.27 \\
\hline \multicolumn{5}{|l|}{$A B C-D L B C L$} \\
\hline B-symptoms & $1.24(0.78-1.96)$ & 0.37 & $1.25(0.79-2.00)$ & 0.34 \\
\hline Nuclear p-AKT high & $1.43(0.88-2.30)$ & 0.15 & $1.45(0.90-2.34)$ & 0.13 \\
\hline
\end{tabular}

$A B C$, activated B-cell-like; DLBCL, diffuse large B-cell lymphoma; GCB, germinal center B-cell-like; HR, hazard ratio; IPI, International Prognostic Index; p-AKT ${ }^{\text {high }}$, high levels $(\geq 70 \%)$ of phospho-AKT expression.

\section{MK-2206 Reduces AKT Phosphorylation and Impairs DLBCL Cell Viability}

As another approach to unravel the regulation and role of p-AKT in DLBCL and to assess the therapeutic potential of targeting AKT, we investigated the antilymphoma activity of the AKT inhibitor MK-2206 in a panel of human DLBCL cell lines (17 GCB-DLBCL and 9 ABC-DLBCL cell lines). Cells were treated with increasing doses of MK-2206 (0 to 25 $\mu \mathrm{mol} / \mathrm{L}$ ) for 48 hours and cell viability was assessed. Similar
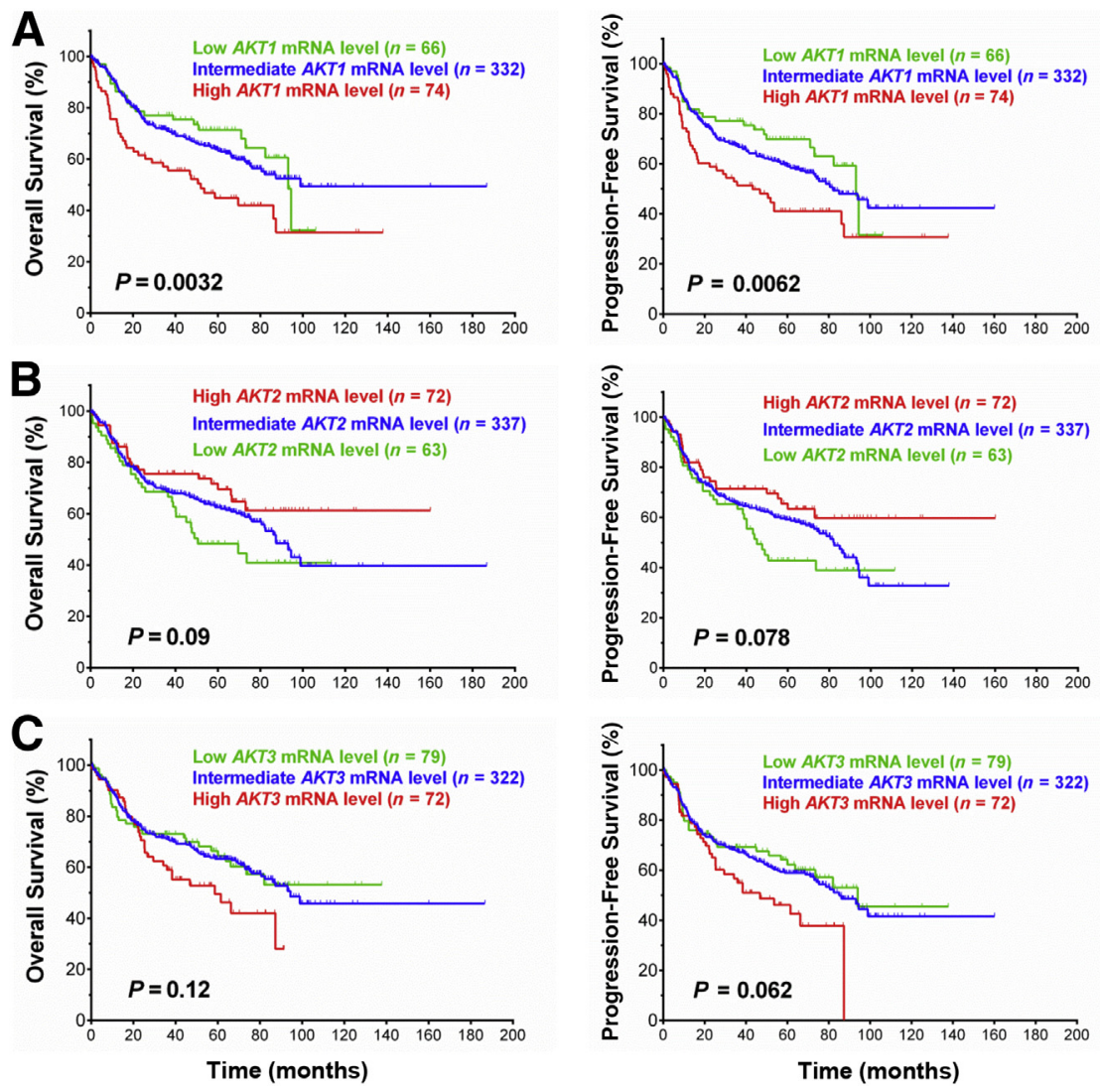
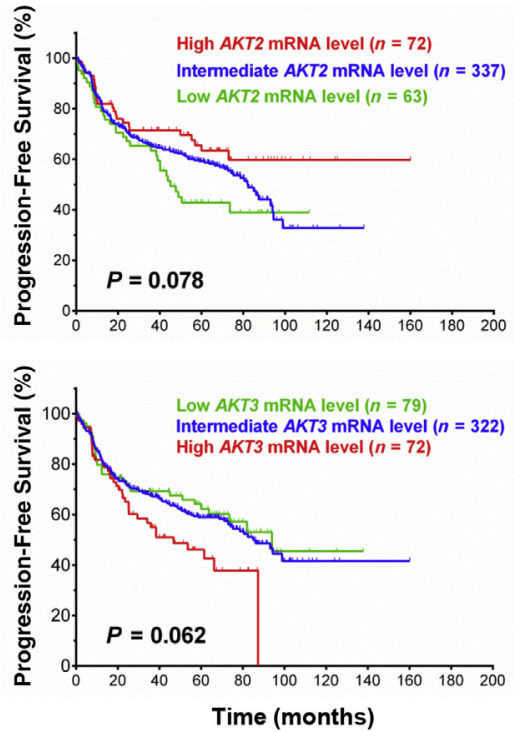

Figure 3 Prognostic impact of AKT1/2/3 mRNA expression on overall survival, and progression-free survival rates in patients with diffuse large B-cell lymphoma. 

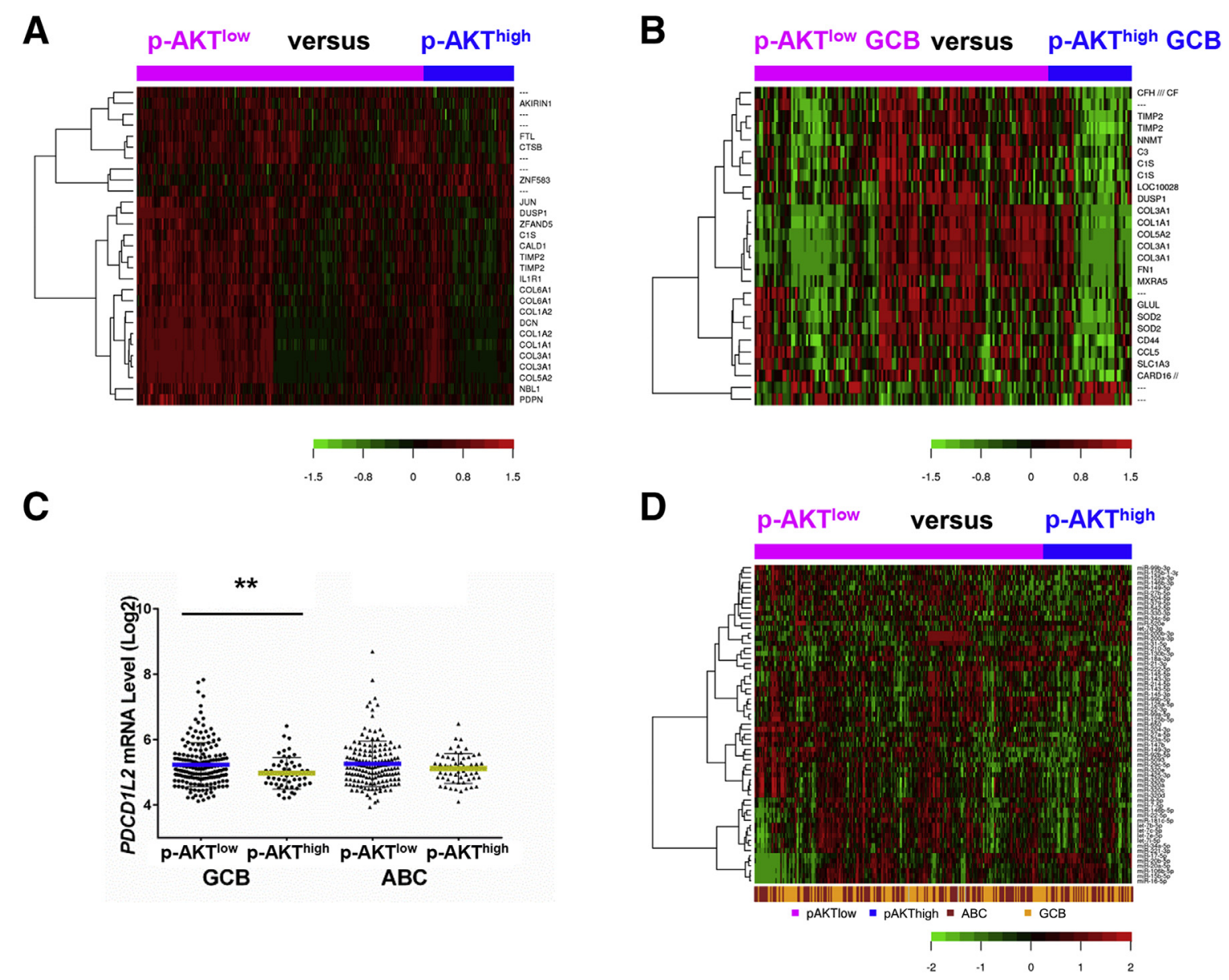

Figure 4 Gene expression profiling and miRNA profiling analysis for phosphorylated-AKT (p-AKT) expression. A and B: Genes significantly differentially expressed between patients with high and low levels of $p$-AKT expression ( $\mathrm{P}-\mathrm{AKT} \mathrm{T}^{\text {high }}$ and $\mathrm{p}$-AKT ${ }^{\mathrm{low}}$ ) in the overall diffuse large B-cell lymphoma (DLBCL) cohort (false discovery rate $<0.01)(A)$ and in the germinal center B-cell-like $(\mathrm{GCB})$ subgroup (false discovery rate $<0.05$, fold change $>1.68)(B)$. C: The $p$-AKT $T^{\text {high }}$ group has significantly lower levels of PDCD1L2 mRNA expression than the $\mathrm{p}$-AKT ${ }^{\text {low }}$ group in GCB-DLBCL. D: miRNAs whose mean levels show significant differences between the $\mathrm{p}$-AKT $\mathrm{T}^{\text {high }}$ and $\mathrm{p}-\mathrm{AKT}{ }^{\text {low }}$ groups. ${ }^{* *} P<0.01$. ABC, activated B-cell-like.

to previous studies in other cell lines, ${ }^{16,35}$ exposure to MK2206 impaired cell viability in a dose-dependent manner. The reduction in cell viability was modest in most cell lines with $\mathrm{IC}_{50}$ values ranging from 0.5 to $20 \mu \mathrm{mol} / \mathrm{L}$ (Figure $6 \mathrm{~A}$ ). MK-2206 treatment decreased AKT phosphorylation but did not affect total AKT levels in most DLBCL lines (Figure 6B). MK-2206-sensitive cells expressed a significantly higher level of p-AKT than MK-2206-resistant cells (Figure 6C). Spearman's rank correlation between MK-2206 sensitivity and p-AKT activity was significant in the representative DLBCL cell lines (Figure 6D).

\section{MK-2206 Inhibits AKT Signaling but Also Induces mTORC2 and Compensatory Signaling Pathways}

To understand the mechanisms of action of MK-2206, we comprehensively analyzed the alteration of signaling transduction cascades after AKT inhibition using RPPA in two representative DLBCL cell lines, DOHH2 (GCB) and LP (ABC), which were sensitive to MK-2206. Protein lysates were prepared from control and MK-2206-treated
DLBCL cells after MK-2206 treatment (at $\mathrm{IC}_{75}$ ) for 24 or 48 hours. After quality control, expression data for a total of 285 proteins were available for further analysis. Supervised hierarchical clustering detected a set of up-regulated and down-regulated proteins after MK-2206 treatment in each cell line (Figure 7A). Significantly up-regulated and down-regulated proteins were selected to generate a heatmap for each cell line (Figure 7B) and are categorized in Table 5.

p-AKT $\left(\mathrm{Ser}^{473}\right)$ levels in both cell lines decreased significantly after MK-2206 treatment; p-AKT $\left(\mathrm{Thr}^{308}\right.$ ) levels were also down-regulated in DOHH2 cells. Downstream targets of AKT phosphorylation such as p-GSK-3b, p-FoxO3a, p-eukaryotic translation initiation factor 4Ebinding protein 1 (4E-BP1), p-PRAS40, mTOR, eukaryotic translation initiation factor $4 \mathrm{G}$ (eIF4G), p-p70-S6K, CyclinB1/D1, FoxM1, XIAP, Hexokinase-II, hypoxia-inducible factor (HIF)- $1 \alpha$, and vascular endothelial growth factor receptor (VEGFR)-2 were also down-regulated in DOHH2/LP cells (Figure 7, C and D), whereas TSC-2, p27-Kip-1, Bim, $\mathrm{BAD}$, bcl2-associated $\mathrm{X}$ protein (Bax), FoxO3a, cleaved 
Table 4 Genes Significantly Differentially Expressed between p-AKT Tigh and p-AKT ${ }^{\text {low }}$ Cases in Overall DLBCL and in GCB-DLBCL

\begin{tabular}{|c|c|c|c|}
\hline \multirow[b]{2}{*}{ Functional categories } & \multirow{2}{*}{$\frac{\text { In } \mathrm{DLBCL}(\mathrm{FDR}<0.01)}{\text { Down-regulated genes }}$} & \multicolumn{2}{|l|}{ In GCB-DLBCL (FDR < 0.05) } \\
\hline & & Down-regulated genes & Up-regulated genes \\
\hline $\begin{array}{l}\text { Immune response, cytokine } \\
\text { receptors, chemokine }\end{array}$ & C1S, IL1R1 & $\begin{array}{l}C F H / C F H R 1, C 3, C 1 S, C C L 5, I F N G R 1, C E B P D, \\
\quad H L A-B, B 2 M, H L A-F, C 2, H L A-A, H L A-E, H L A-G\end{array}$ & DEFB126 \\
\hline Apoptosis & & CARD16/CASP1, VDAC3, TMBIM6 & MDM2 \\
\hline Signaling & $N B L 1$ & CD63, SEL1L, PRKAR1A, WDR26, EFHD2, NBL1 & MAP2K5, TSSK3 \\
\hline Gene expression, cell growth & $\begin{array}{l}\text { ZNF583, JUN, DUSP1, } \\
\text { CALD1 }\end{array}$ & $\begin{array}{l}\text { DUSP1, AEBP1, JUN, KLF9, RBPJ, NR3C1, GRN, } \\
\text { LMNA, RUNX1, HNRNPU }\end{array}$ & $\begin{array}{l}\text { RPL37A, ANAPC13, SNAI3, } \\
\quad \text { MRT04, CEP97, HNRNPR, TTF2 }\end{array}$ \\
\hline $\begin{array}{l}\text { Cell adhesion, cytoskeleton, } \\
\text { extracellular matrix, } \\
\text { exocytosis, migration, } \\
\text { metastasis, angiogenesis }\end{array}$ & $\begin{array}{l}\text { TIMP2, COL6A1, COL1A2, } \\
\text { DCN, COL1A1, COL3A1, } \\
\text { COL5A2, PDPN }\end{array}$ & $\begin{array}{l}\text { MXRA5, FN1, COL5A2, CD44, TIMP2, COL1A1, } \\
\text { BGN, SRGN, PARVA, ITGB2, DPYSL3, MMP2, } \\
\text { LAMP2, DST, SPARC, WDR1, TLN1, PDLIM5, } \\
\text { PSAP, SERPINF1, MIR21/TMEM49, CAPNS1, } \\
\text { ANXA7, ACTG1, EXOC4, SH3PXD2A, DYNLL2, } \\
\text { ABHD2, ACTB }\end{array}$ & JPH1 \\
\hline Metabolism & $F T L$ & $\begin{array}{l}\text { SOD2, NNMT, GLUL, ALDH2, FTH1, PIGY, } \\
\text { B4GALT1, FTL, APOE, CYBRD1, SERINC1, } \\
\text { RNASEK, CSGALNACT2, GLRX, PPP1CA, GPX4, } \\
\text { GPD2, GALC, CYB5R3, TATDN2 }\end{array}$ & ATAD3B, FXN, AGPAT5 \\
\hline $\begin{array}{l}\text { Degradation, protein folding, } \\
\text { sorting, transport, } \\
\text { trafficking }\end{array}$ & CTSB, ZFAND5 & $\begin{array}{l}\text { SLC1A3, RAB31, ZFAND5, CALU, USP36, } \\
\text { UBE2L6, ATP6VOE1, ARNT, RAB35, SEC23B, } \\
\text { DNAJC3, SERINC3, PICALM, STX4, VPS53, } \\
\text { AP2S1 }\end{array}$ & FKBP6, KCNK1, FBX038, CACYBP \\
\hline Differentiation & & AHNAK, SLFN5 & \\
\hline Unknown function & AKIRIN1 & $\begin{array}{l}\text { LOC100288387, LOC100129500, AKIRIN1, } \\
\text { MARVELD1, TMEM140 }\end{array}$ & $\begin{array}{l}\text { C3orf53, C6orf58, CXorf61, } \\
\text { LOC100129069, C18orf18, } \\
\text { PDZK1P1, LOC440957, RNFT2 }\end{array}$ \\
\hline
\end{tabular}

The order of genes is based on fold-changes.

DLBCL, diffuse large B-cell lymphoma; FDR, false discovery rate; GCB, germinal center B-cell-like; $\mathrm{p}-\mathrm{AKT} \mathrm{T}^{\text {high }}$, high levels ( $\left.\geq 70 \%\right)$ of phospho-AKT expression; p-AKT ${ }^{\text {low }}$, low levels $(<70 \%)$ of phospho-AKT expression.

caspases, and E-Cadherin expression (but not GSK-3ab) were up-regulated. In addition to the down-regulation of proteins involved in cell cycle progression (eg, Cyclin-B1/ D1, CDK1, FoxM1, and Aurora B), proteins involved in DNA repair [eg, checkpoint kinase 1 (ChK1), ataxia telangiectasia and Rad3-related, MutS protein homolog 2, MutS protein homolog 6, Rad51, and proliferating cell nuclear antigen (PCNA) and the tumor suppressors retinoblastoma protein and polo-like kinase 1 were also down-regulated in DOHH2 and/or LP cells after MK-2206 treatment (Table 5)].

However, similar to a common phenomenon observed in the use of mTOR inhibitors resulting from the loss of a negative feedback loop, ${ }^{8,9}$ Rictor (mTORC2) and PI3K, which activate p-AKT; protein tyrosine kinase p-FAK and adaptor protein GRB2-associated binding protein 2, which activate $\mathrm{PI} 3 \mathrm{~K}$; and $\mathrm{p}$-mitogen-activated protein kinase (MAPK) kinase 1 (MEK1), p-p38 (MAPK14), and pMAPK (ERK2), which suggest activation of compensatory signaling, were up-regulated in DOHH2 cells after MK2206 treatment; tyrosine kinase receptors platelet-derived growth factor receptor (PDGFR) $\beta$ and Axl (which activate $\mathrm{PI} 3 \mathrm{~K}$ and AKT signaling), protein kinase Cs (PKCs) (downstream of PDGFR and PI3K and regulated by mTORC2), protein tyrosine kinase Lck, scaffolding protein Caveolin-1, receptor proteinase-activated receptor, and
p-NF-кB-p65 were up-regulated in both DOHH2 and LP cells; Notch1 and Notch3 were up-regulated in LP cells after MK-2206 treatment. In contrast, p-HER3, focal adhesion kinase (FAK), MEK1, and C-Raf were down-regulated in DOHH2 and/or LP cells. PTEN and Src homology region-2 that negatively regulate the PI3K signaling were upregulated in DOHH2 cells after MK-2206 treatment (Table 5).

Likely because of the enhanced mTORC2 activity, activation of the compensatory pathways, and decreased GSK$3 \mathrm{ab}$ expression (Table 5), ${ }^{10,36,37}$ antiapoptotic Bcl-2 and Mcl-1 after MK-2206 treatment were up-regulated in both DOHH 2 and LP cells. p53 and Myc were up-regulated in LP cells but down-regulated in DOHH2 cells after MK-2206 treatment. Beclin (essential for autophagy) was upregulated in DOHH2 cells. In addition, programmed cell death protein 1 ligand 1 (PD-L1) expression mediating immunosuppression was significantly increased after MK2206 treatment in LP cells (Table 5).

\section{Discussion}

Here, we explored the role and regulation of AKT activation in DLBCL and the potential for AKT-targeted therapy. We show that overexpression of nuclear p-AKT $\left(\operatorname{Ser}^{473}\right)$ 

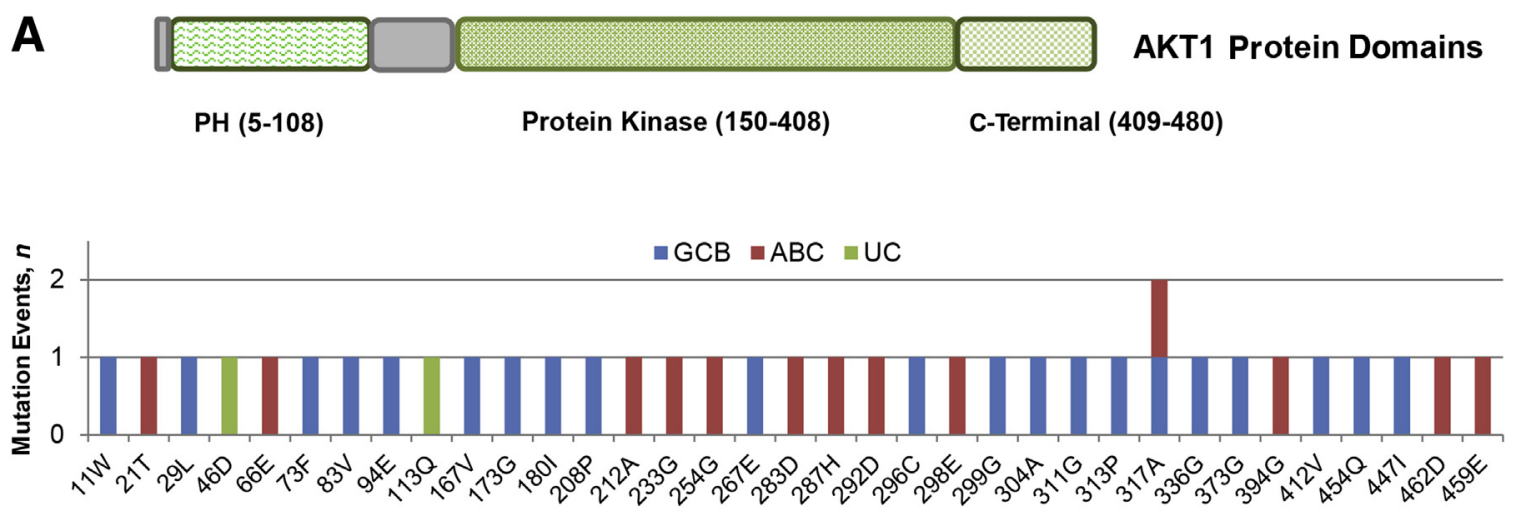

B

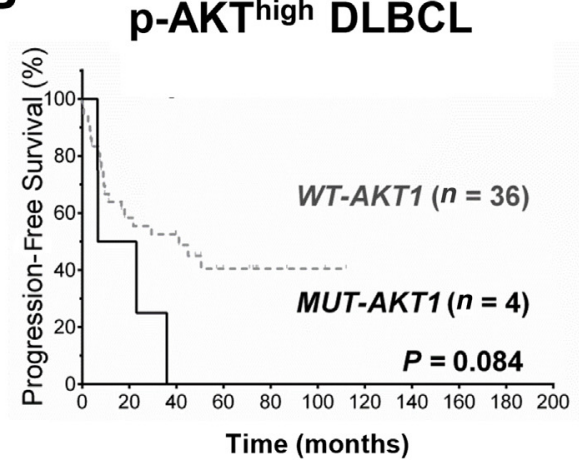

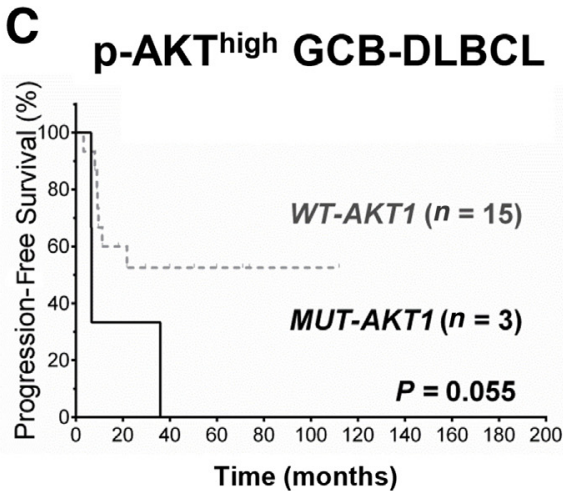

Figure 5 AKT1 mutation analysis. A: Illustration of the AKT1 protein domains and AKT1 mutations observed in the patients with diffuse large B-cell lymphoma (DLBCL). B and C: Among patients with high levels of phosphorylated AKT ( $\mathrm{p}-\mathrm{AK} \mathrm{T}^{\text {high }}$ ), patients with AKT1 mutations (MUT) tend to have poorer progression-free survival than patients with wild-type (WT) AKT1 in the overall DLBCL cohort (B) and in the germinal center B-cell-like (GCB) subgroup (C). $\mathrm{ABC}$, activated B-cell-like; $\mathrm{PH}$, pleckstrin homology; UC, unclassifiable.

$\left(\geq 70 \%\right.$, p-AKT ${ }^{\text {high }}$ ) was associated with significantly poorer PFS in DLBCL patients treated with R-CHOP. However, $\mathrm{p}^{-\mathrm{AKT}^{\text {high }}}$ was associated with $\mathrm{Bcl}-2$ and Myc overexpression, and multivariate analysis indicated that $\mathrm{p}$ $\mathrm{AKT}^{\text {high }}$ was not an independent prognostic factor for poorer survival. Such a prognostic effect of p-AKT (significant in the univariate analysis but not in the multivariate analysis) was also observed by an earlier study in a smaller patient cohort $(n=97){ }^{23}$ These data suggest that the adverse impact of AKT activation is indirect and depends on downstream effectors. ${ }^{11}$ It is also possible that the adverse prognostic impact of AKT for patients treated with R-CHOP has been mitigated because rituximab could inhibit AKT signaling, ${ }^{38}$ whereas AKT signaling up-regulates CD20 levels. ${ }^{39}$ The overlapping but also independent regulation and function of p-AKT $\left(\mathrm{Ser}^{473}\right)$ and p-AKT $\left(\mathrm{Thr}^{308}\right)$ may also have confounded the analysis. Although phosphorylation at $\mathrm{Ser}^{473}$ is generally thought necessary for the full activation of p-AKT, ${ }^{9,10,40}$ p-AKT $\left(\mathrm{Thr}^{308}\right)$ in the absence of phospho-Ser ${ }^{473}$ can have partial function. ${ }^{41}$ In addition, it is unclear whether the p-AKT $\left(\mathrm{Ser}^{473}\right)$ antibody we used crossreacts with the p-AKT2 $\left(\mathrm{Ser}^{474}\right)$ and p-AKT3 $\left(\mathrm{Ser}^{472}\right)$ isoforms. Notably, mRNA expression of $A K T 1$ and $A K T 2$, the two commonly expressed isoforms, was associated with opposite prognostic impact in this DLBCL cohort
(Figure 3). Despite the limitation of its prognostic impact, pAKT hyperactivation may provide important information after the prognostic stratification by Myc and Bcl-2, however, because it was associated with significantly poorer PFS in patients with low levels of Myc or Bcl-2 expression (Figure 2).

GEP analysis showed that many immune-related genes were down-regulated in the $\mathrm{p}-\mathrm{AKT} \mathrm{T}^{\text {high }}$ group, particularly in GCB-DLBCL, whereas $M D M 2$ and $M A P 2 K$ which protect cells from apoptosis were up-regulated. Surprisingly, many genes involved in metabolism and the cytoskeleton were also down-regulated in the $\mathrm{p}-\mathrm{AKT}^{\text {high }}$ group, opposite to the functions of AKT and mTOR. It is possible that the major function of AKT is mediated through post-translational modification rather than at the transcriptional level. In addition, the identified $\mathrm{p}-\mathrm{AKT}^{\text {high }}$ signatures showed similarity to the $\mathrm{Myc}^{\text {high }}$ and $\mathrm{p} 50^{\text {low }}$ GEP signatures (data not shown), likely caused by the positive/negative correlation of p-AKT ${ }^{\text {high }}$ with these two transcription factors.

Regarding AKT hyperactivation mechanisms, AKT1 is rarely amplified in DLBCL, ${ }^{5,42}$ but several upstream genetic alterations have been implicated, such as deletion or mutation of PTEN ${ }^{43,44}$ and PIK3CA mutations. ${ }^{45}$ An activating mutation in the AKT PH domain E17K has been shown in solid tumors conferring resistance to AKT inhibitors. ${ }^{46}$ In 
A

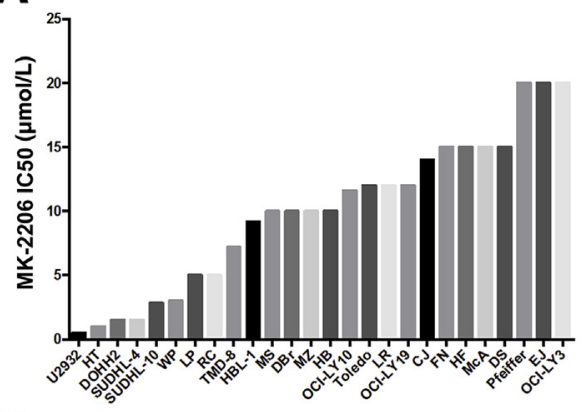

C

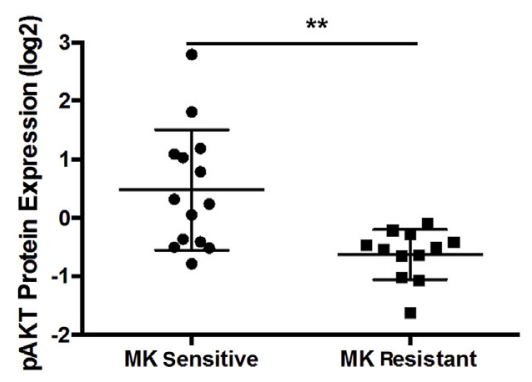

B
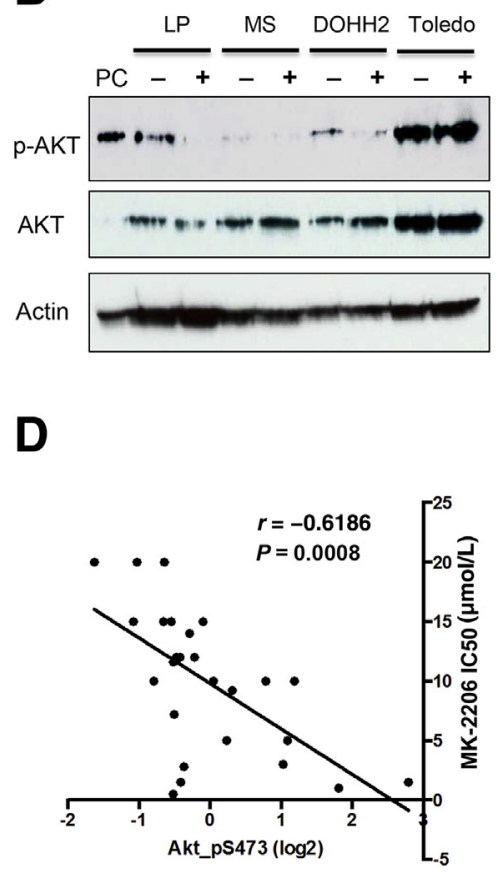

Figure 6 Pharmacologic AKT inhibition by MK2206 in diffuse large B-cell lymphoma (DLBCL) cell lines. A: The effect of 48 hours of MK-2206 treatment on the viability of human patientderived DLBCL cell lines relative to cells treated with dimethylsulfoxide control. B: Western blot analysis results of phosphorylated AKT (p-AKT) and total AKT protein expression in LP, MS, DOHH2, and Toledo cell lines after incubation with 20 $\mu \mathrm{mol} / \mathrm{L}$ MK-2206 for 48 hours. C: Comparison of pAKT expression in MK-2206-sensitive versus -resistant cell lines. MK-2206 $\mathrm{IC}_{50}$ of $\leq 10 \mu \mathrm{mol} / \mathrm{L}$ is considered sensitive and $\mathrm{IC}_{50}>10 \mu \mathrm{mol} / \mathrm{L}$ is considered resistant. D: p-AKT assessed by RPPA is plotted against the corresponding MK-2206 $\mathrm{IC}_{50}$ in 26 representative DLBCL cell lines. Waterfall graph shows the $\mathrm{IC}_{50}$ value of MK-2206 for each cell line (A). Correlation coefficient was determined by the Spearman's rank correlation and two-tailed $t$-test. ${ }^{*} P<0.01$. PC, positive control; RPPA, reversephase protein array. this study we did not observe the activating E17K mutation or a significant prognostic impact of AKT mutations. Although the four patients with nuclear overexpression of AKT mutants tended to have a poorer prognosis, the number of patients is small and the poorer survival can be attributable to other genetic lesions (MYC, BCL2, or BCL6 rearrangement, or TP53 deletion).

Instead, our analysis suggested the IL-6/PI3K signaling pathway and epigenetic regulation by miRNAs played important roles for AKT hyperactivation in DLBCL. We identified 63 miRNAs that were significantly differentially expressed between the $\mathrm{p}-\mathrm{AKT}^{\text {high }}$ and $\mathrm{p}-\mathrm{AKT}^{\text {low }}$ groups. Among the down-regulated miRNAs in the $\mathrm{p}-\mathrm{AKT}^{\text {high }}$ group, miR-143 has been shown to have antioncogenic function by repressing both the PI3K/AKT and MAPK pathways. $^{47}$ In contrast, miR-17-5p, which targets PTEN that negatively regulates the PI3K/AKT pathway, ${ }^{48}$ was up-regulated in the $\mathrm{p}-\mathrm{AKT}^{\text {high }}$ group.

AKT is thought to be an effective therapeutic target in cancers with $\mathrm{PI} 3 \mathrm{~K} / \mathrm{AKT} / \mathrm{mTOR}$ activation ${ }^{49}$ and in tumors that are not driven by AKT activation. ${ }^{12}$ The antitumor activity of MK-2206 is greater in some, but not all, breast cancer cell lines with PTEN loss or PIK3CA mutation. ${ }^{50}$ Our data show that the sensitivity of MK-2206 in DLBCL cell lines correlated with AKT activation status, suggesting the on-target effect of MK-2206 in DLBCL cells. Interestingly, DOHH2 cells (GCB-DLBCL with $M Y C / B C L 2$ rearrangements and wild-type p53) and LP (ABC-DLBCL with mutated p53) cells demonstrated high MK-2206 sensitivity. In vitro studies have shown that $\mathrm{AKT}$ activation increases Myc protein stability owing to the inhibition of GSK-3. ${ }^{51}$ In mouse models, AKT activation and Myc expression exhibit synergistic actions in aggressive B-cell lymphomagenesis. ${ }^{52}$ After tumor onset in $p 53^{-/-}$mice, AKT1 ablation resulted in regression of thymic lymphoma and increased the life span of $p 53^{-/-}$mice. $^{12}$ The antilymphoma activity of MK-2206 observed in DOHH2 and LP DLBCL cell lines, and the correlation between p-AKT overexpression and $M Y C$ rearrangement and $\mathrm{Myc} / \mathrm{Bcl}-2$ overexpression observed in this DLBCL cohort, may suggest indirect targeting strategies for DLBCL with aggressive oncogenic drivers.

We further analyzed AKT signaling using RPPA, a high-throughput antibody-based technique for proteomics studies. In line with the impaired cell viability, after MK-2206 treatment, p-AKT $\left(\operatorname{Ser}^{473}\right)$ and phosphorylated targets were down-regulated, as shown by down-regulation of p-GSK-3b, p-FoxO3a, p-4E-BP1, p-p70-S6K, p-S6, p-PRAS40, and p-yes-associated protein. mTOR, HIF-1 $\alpha$, XIAP, VEGFR-2, Cyclin-B1, FoxM1, Cyclin-D1, eIF4G, and Hexokinase-II, whereas p27-Kip-1, BAD, p53 up-regulated modulator of apoptosis, Bim, Bax, Bak, E-Cadherin, FoxO3a, Beclin, and caspases (cleaved) were up-regulated. However, several upstream proteins were also up-regulated, such as Rictor (mTORC2), PI3K, PDGFR $\beta$, Caveolin-1, Lck, p-FAK, and Axl (therefore p-PKC/PKC), and MEK1, p38, and MAPK were activated likely as compensatory pathways for AKT function after pharmacologic inhibition. NF- $\mathrm{B}-\mathrm{p} 65-\mathrm{pS} 536$ (which was also up-regulated by PI3K inhibitors) ${ }^{53}$ and Notch1/3 were also induced. The limited efficacy of MK-2206 also may be explained by the up-regulation of Bcl-2 and Mcl-1 and down-regulation of GSK-3ab and proteins involved in DNA damage and repair. However, decreased DNA repair may suggest synergy between MK-2206 and radiotherapy. ${ }^{42}$ 


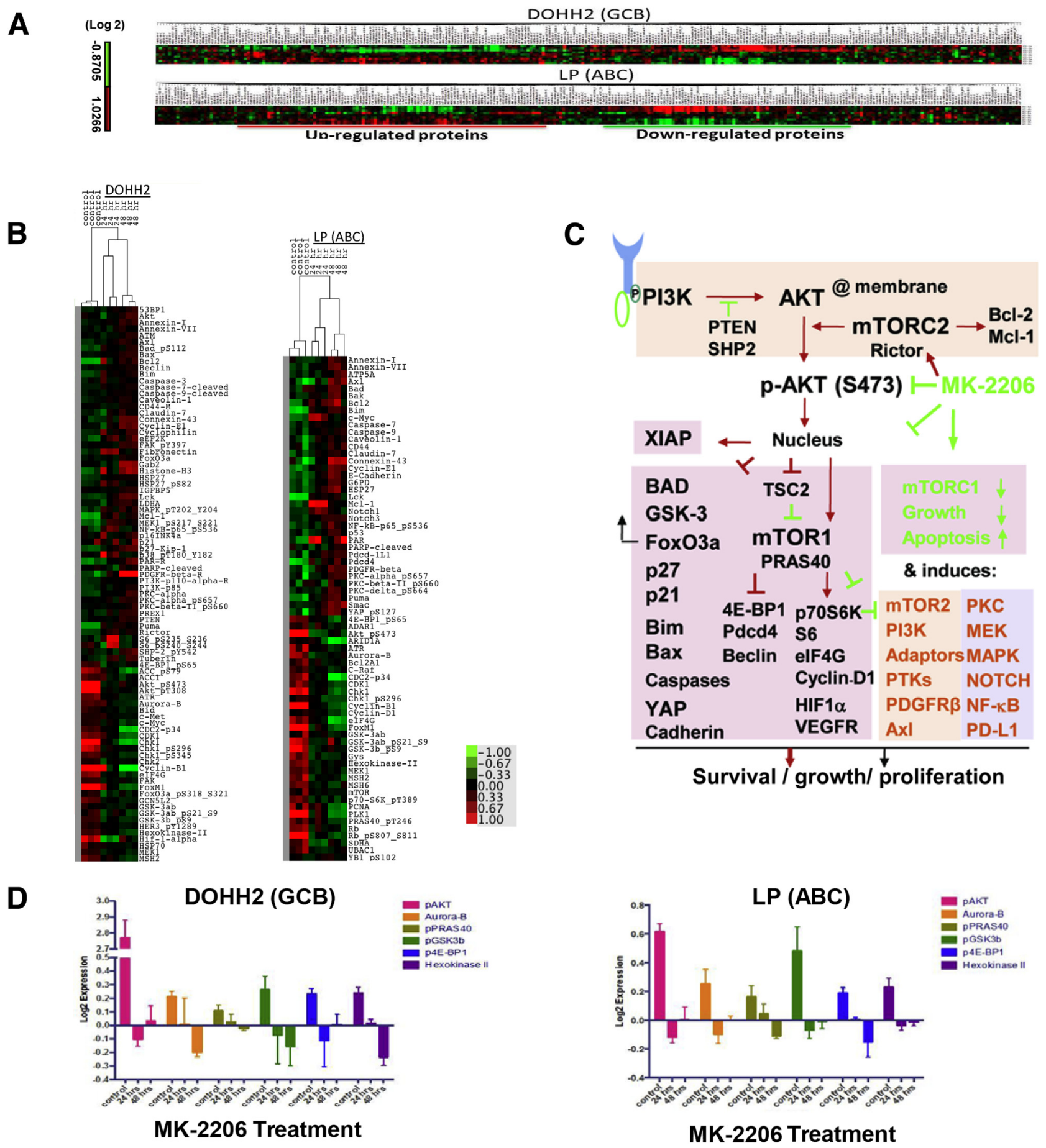

Figure 7 Reverse-phase protein array analysis in MK-2206-treated DOHH2 and LP cell lines. A: Supervised hierarchical clustering heatmap of 285 proteins analyzed in $\mathrm{DOHH} 2$ and LP cell lines. For each heatmap, the top three rows are triplicate controls, and the bottom six rows are MK-2206 (IC 75 ) treatment for 24 and 48 hours, respectively. B: Heatmap for significantly up-regulated and down-regulated proteins in DOHH2 and LP cell lines after MK-2206 treatment. Red and green bars indicate up-regulation and down-regulation, respectively. C: Schematic illustration of the alterations of AKT signaling pathways after MK-2206 treatment. Detailed descriptions are in the main text. Green arrows and blunted lines indicate tumor-suppressing effects; red arrows and blunted lines indicate tumor-promoting effects. D: Examples of down-regulated phosphorylated AKT (pAKT) and AKT target proteins significant in both DOHH2 and LP cell lines after MK-2206 treatment. ABC, activated B-cell-like; GCB, germinal center B-cell-like; PTK, protein tyrosine kinase.

Notably, p53, Myc, and PD-L2 expression were upregulated in LP cells (ABC-DLBCL with mutated p53) after AKT inhibition. In this DLBCL cohort, $\mathrm{p}-\mathrm{AKT}^{\text {high }}$ was associated with significantly lower $P D-L 2$ mRNA expression in GCB-DLBCL (Figure 4C), and a trend to lower
$P D$ - $L 1$ mRNA expression in ABC-DLBCL $(P=0.16)$. These results provide insights into the efficacy of MK-2206 as a single agent and suggest that MK-2206 may be more effective when combined with $\mathrm{PI} 3 \mathrm{~K} / \mathrm{mTORC} 2 / 1 / \mathrm{Bcl}-2 /$ Mcl-1/PD-L1 inhibitors. 
Table 5 Up- and Down-Regulated Proteins after MK-2206 Treatment in DOHH2 and LP Cell Lines

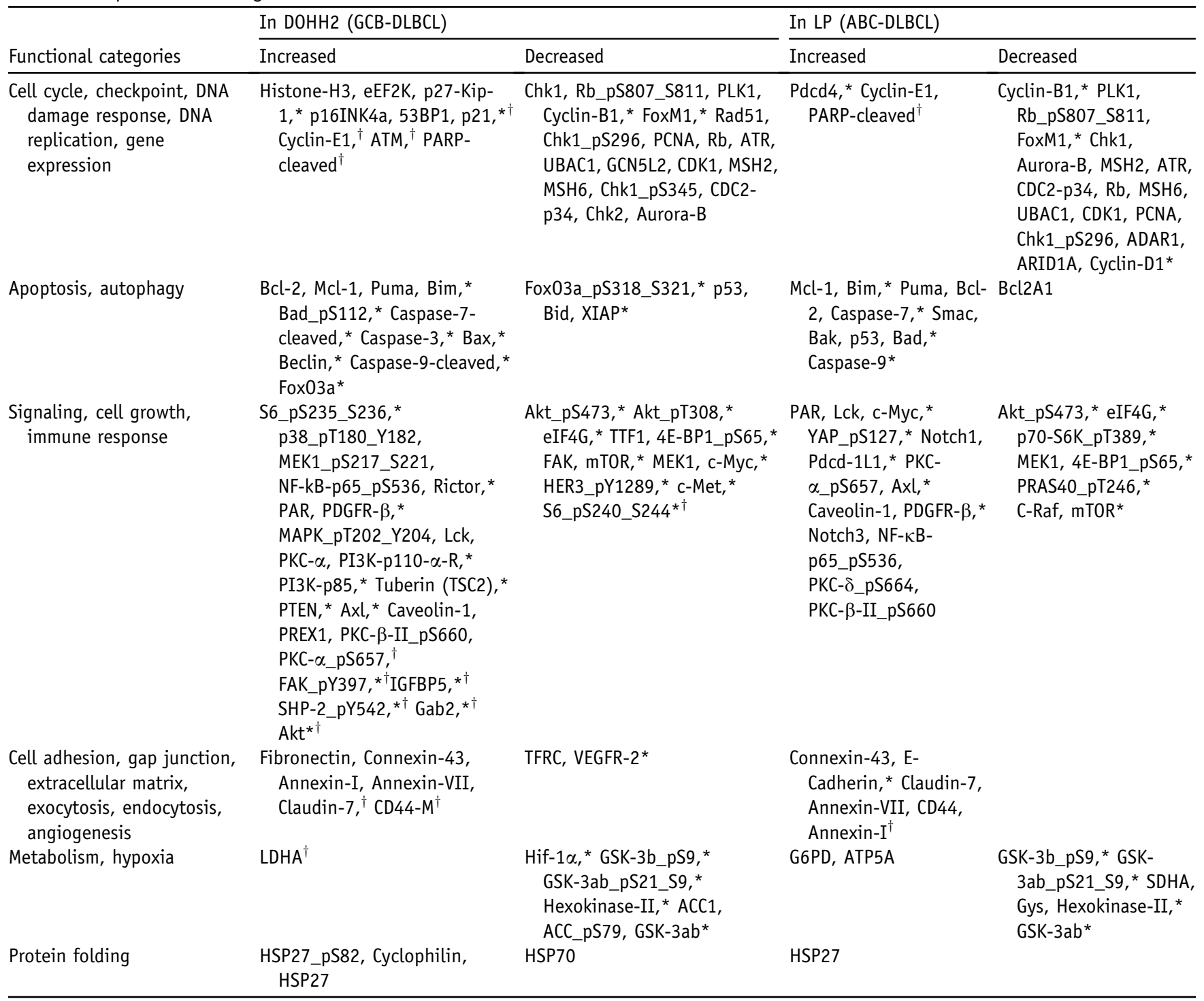

The order of proteins is according to the fold-change at 24 hours after treatment.

*Proteins upstream or downstream of AKT signaling and Pdcd-1L1.

${ }^{\dagger}$ Proteins that showed increase only at 48 hours.

$A B C$, activated B-cell-like; DLBCL, diffuse large B-cell lymphoma; GCB, germinal center B-cell-like.

\section{Conclusions}

This study demonstrated that AKT hyperactivation in approximately one-fourth of DLBCL patients was associated with significantly inferior PFS. Although this prognostic impact may depend on other associated oncogenic events, evaluation of p-AKT expression is helpful for prognostic stratification and therapy selection. Pharmacologic inhibition of AKT impaired AKT signaling and lymphoma cell viability in vitro. However, targeting AKT as monotherapy has limited efficacy owing to the induction of upstream and compensatory signaling pathways, and combination therapies are needed. These results have clinical and therapeutic implications for DLBCL with AKT hyperactivation and potentially also for DLBCL with $\mathrm{MYC/}$ TP53 abnormalities.

\section{Acknowledgments}

J.W., Z.Y.X.-M., and K.H.Y. designed and conducted the research and performed the statistical analysis; J.W., Z.Y.X.-M., K.J.J., Q.S., G.C.M., A.T., C.V., J.W., S.M.-M., K.D., W.T., G.B., E.D.H., J.H.v.K., M.P., A.J.M.F., S.W., M.B.M., M.A.P., L.J.M., Y.L., L.V.P., and K.H.Y. contributed vital new reagents, resources, technology, and analytical tools; J.W., Z.Y.X.-M., K.J.J., Q.S., A.T., C.V., S.M.-M., K.D., W.T., G.B., E.D.H., J.H.v.K., M.P., 
A.J.M.F., M.B.M., M.A.P., and K.H.Y. collected clinical and follow-up data under approval by the institutional review boards and the material transfer agreement; J.W., Z.Y.X.-M., and K.H.Y. wrote the manuscript; all authors contributed vital strategies, participated in discussions, provided scientific input, and edited manuscript.

\section{References}

1. Alizadeh AA, Eisen MB, Davis RE, Ma C, Lossos IS, Rosenwald A, Boldrick JC, Sabet H, Tran T, Yu X, Powell JI, Yang L, Marti GE, Moore T, Hudson J Jr, Lu L, Lewis DB, Tibshirani R, Sherlock G, Chan WC, Greiner TC, Weisenburger DD, Armitage JO, Warnke R, Levy R, Wilson W, Grever MR, Byrd JC, Botstein D, Brown PO, Staudt LM: Distinct types of diffuse large B-cell lymphoma identified by gene expression profiling. Nature 2000, 403:503-511

2. Staudt LM, Dave S: The biology of human lymphoid malignancies revealed by gene expression profiling. Adv Immunol 2005, 87: $163-208$

3. Hans CP, Weisenburger DD, Greiner TC, Gascoyne RD, Delabie J, Ott G, Muller-Hermelink HK, Campo E, Braziel RM, Jaffe ES, Pan Z, Farinha P, Smith LM, Falini B, Banham AH, Rosenwald A, Staudt LM, Connors JM, Armitage JO, Chan WC: Confirmation of the molecular classification of diffuse large B-cell lymphoma by immunohistochemistry using a tissue microarray. Blood 2004, 103: 275-282

4. Visco C, Li Y, Xu-Monette ZY, Miranda RN, Green TM, Li Y, et al: Comprehensive gene expression profiling and immunohistochemical studies support application of immunophenotypic algorithm for molecular subtype classification in diffuse large B-cell lymphoma: a report from the International DLBCL Rituximab-CHOP Consortium Program Study. Leukemia 2012, 26:2103-2113

5. Franke TF, Hornik CP, Segev L, Shostak GA, Sugimoto C: PI3K/Akt and apoptosis: size matters. Oncogene 2003, 22:8983-8998

6. Davies MA: Regulation, role, and targeting of Akt in cancer. J Clin Oncol 2011, 29:4715-4717

7. Stambolic V, Suzuki A, de la Pompa JL, Brothers GM, Mirtsos C, Sasaki T, Ruland J, Penninger JM, Siderovski DP, Mak TW: Negative regulation of $\mathrm{PKB} / \mathrm{Akt}$-dependent cell survival by the tumor suppressor PTEN. Cell 1998, 95:29-39

8. Robbins HL, Hague A: The PI3K/Akt pathway in tumors of endocrine tissues. Front Endocrinol (Lausanne) 2016, 6:188

9. Guertin DA, Sabatini DM: Defining the role of mTOR in cancer. Cancer Cell 2007, 12:9-22

10. Vadlakonda L, Dash A, Pasupuleti M, Anil Kumar K, Reddanna P: The paradox of Akt-mTOR interactions. Front Oncol 2013, 3:165

11. Skeen JE, Bhaskar PT, Chen CC, Chen WS, Peng XD, Nogueira V, Hahn-Windgassen A, Kiyokawa H, Hay N: Akt deficiency impairs normal cell proliferation and suppresses oncogenesis in a p53independent and mTORC1-dependent manner. Cancer Cell 2006, 10:269-280

12. Yu WN, Nogueira V, Sobhakumari A, Patra KC, Bhaskar PT, Hay N: Systemic Akt1 deletion after tumor onset in p53(-/-) mice increases lifespan and regresses thymic lymphoma emulating p53 restoration. Cell Rep 2015, 12:610-621

13. Mayer IA, Arteaga CL: The PI3K/akt pathway as a target for cancer treatment. Annu Rev Med 2016, 67:11-28

14. Yap TA, Yan L, Patnaik A, Fearen I, Olmos D, Papadopoulos K, Baird RD, Delgado L, Taylor A, Lupinacci L, Riisnaes R, Pope LL, Heaton SP, Thomas G, Garrett MD, Sullivan DM, de Bono JS, Tolcher AW: First-in-man clinical trial of the oral pan-AKT inhibitor MK-2206 in patients with advanced solid tumors. J Clin Oncol 2011, 29:4688-4695

15. Yap TA, Yan L, Patnaik A, Tunariu N, Biondo A, Fearen I, Papadopoulos KP, Olmos D, Baird R, Delgado L, Tetteh E,
Beckman RA, Lupinacci L, Riisnaes R, Decordova S, Heaton SP, Swales K, deSouza NM, Leach MO, Garrett MD, Sullivan DM, de Bono JS, Tolcher AW: Interrogating two schedules of the AKT inhibitor MK-2206 in patients with advanced solid tumors incorporating novel pharmacodynamic and functional imaging biomarkers. Clin Cancer Res 2014, 20:5672-5685

16. Konopleva MY, Walter RB, Faderl SH, Jabbour EJ, Zeng Z, Borthakur G, Huang X, Kadia TM, Ruvolo PP, Feliu JB, Lu H, Debose L, Burger JA, Andreeff M, Liu W, Baggerly KA, Kornblau SM, Doyle LA, Estey EH, Kantarjian HM: Preclinical and early clinical evaluation of the oral AKT inhibitor, MK-2206, for the treatment of acute myelogenous leukemia. Clin Cancer Res 2014, 20: 2226-2235

17. Petrich AM, Leshchenko V, Kuo PY, Xia B, Thirukonda VK, Ulahannan N, Gordon S, Fazzari MJ, Ye BH, Sparano JA, Parekh S: Akt inhibitors MK-2206 and nelfinavir overcome mTOR inhibitor resistance in diffuse large B-cell lymphoma. Clin Cancer Res 2012, 18:2534-2544

18. Dai DL, Martinka M, Li G: Prognostic significance of activated Akt expression in melanoma: a clinicopathologic study of 292 cases. J Clin Oncol 2005, 23:1473-1482

19. Schmitz KJ, Otterbach F, Callies R, Levkau B, Holscher M, Hoffmann O, Grabellus F, Kimmig R, Schmid KW, Baba HA: Prognostic relevance of activated Akt kinase in node-negative breast cancer: a clinicopathological study of 99 cases. Mod Pathol 2004, 17: $15-21$

20. Min YH, Eom JI, Cheong JW, Maeng HO, Kim JY, Jeung HK, Lee ST, Lee MH, Hahn JS, Ko YW: Constitutive phosphorylation of Akt/PKB protein in acute myeloid leukemia: its significance as a prognostic variable. Leukemia 2003, 17:995-997

21. Rudelius M, Pittaluga S, Nishizuka S, Pham TH, Fend F, Jaffe ES, Quintanilla-Martinez L, Raffeld M: Constitutive activation of Akt contributes to the pathogenesis and survival of mantle cell lymphoma. Blood 2006, 108:1668-1676

22. Hong JY, Hong ME, Choi MK, Kim YS, Chang W, Maeng CH, Park S, Lee SJ, Do IG, Jo JS, Jung SH, Kim SJ, Ko YH, Kim WS: The impact of activated p-AKT expression on clinical outcomes in diffuse large B-cell lymphoma: a clinicopathological study of 262 cases. Ann Oncol 2014, 25:182-188

23. Uddin S, Hussain AR, Siraj AK, Manogaran PS, Al-Jomah NA, Moorji A, Atizado V, Al-Dayel F, Belgaumi A, El-Solh H, Ezzat A, Bavi P, Al-Kuraya KS: Role of phosphatidylinositol 3'-kinase/AKT pathway in diffuse large B-cell lymphoma survival. Blood 2006, 108: 4178-4186

24. Hasselblom S, Hansson U, Olsson M, Toren L, Bergstrom A, Nilsson-Ehle H, Andersson PO: High immunohistochemical expression of p-AKT predicts inferior survival in patients with diffuse large Bcell lymphoma treated with immunochemotherapy. Br J Haematol 2010, 149:560-568

25. Visco C, Tzankov A, Xu-Monette ZY, Miranda RN, Tai YC, Li Y, et al: Patients with diffuse large B-cell lymphoma of germinal center origin with BCL2 translocations have poor outcome, irrespective of MYC status: a report from an International DLBCL rituximab-CHOP Consortium Program Study. Haematologica 2013, 98:255-263

26. $\mathrm{Hu} \mathrm{S}$, Xu-Monette ZY, Tzankov A, Green $\mathrm{T}$, Wu L, Balasubramanyam A, et al: MYC/BCL2 protein coexpression contributes to the inferior survival of activated B-cell subtype of diffuse large B-cell lymphoma and demonstrates high-risk gene expression signatures: a report from The International DLBCL Rituximab-CHOP Consortium Program. Blood 2013, 121: 4021-4031. quiz 4250

27. Li L, Xu-Monette ZY, Ok CY, Tzankov A, Manyam GC, Sun R, Zhang L, Montes-Moreno S, Visco C, Tzankov A, Yin L, Dybkaer K, Chiu A, Orazi A, Zu Y, Bhagat G, Richards KL, Hsi ED, Choi WW, van Krieken JH, Huh J, Ponzoni M, Ferreri AJ, Zhao X, Moller MB, Farnen JP, Winter JN, Piris MA, Pham L, Young KH: Prognostic impact of c-Rel nuclear expression and REL amplification and 
crosstalk between c-Rel and the p53 pathway in diffuse large B-cell lymphoma. Oncotarget 2015, 6:23157-23180

28. Ok CY, Xu-Monette ZY, Li L, Manyam GC, Montes-Moreno S, Tzankov A, Visco C, Dybkaer K, Routbort MJ, Zhang L, Chiu A, Orazi A, Zu Y, Bhagat G, Richards KL, Hsi ED, Choi WW, van Krieken JH, Huh J, Ponzoni M, Ferreri AJ, Parsons BM, Rao H, Moller MB, Winter JN, Piris MA, Wang SA, Medeiros LJ, Young KH: Evaluation of NF-kappaB subunit expression and signaling pathway activation demonstrates that $\mathrm{p} 52$ expression confers better outcome in germinal center B-cell-like diffuse large B-cell lymphoma in association with CD30 and BCL2 functions. Mod Pathol 2015, 28:1202-1213

29. Ok CY, Chen J, Xu-Monette ZY, Tzankov A, Manyam GC, Li L, Visco C, Montes-Moreno S, Dybkaer K, Chiu A, Orazi A, Zu Y, Bhagat G, Richards KL, Hsi ED, Choi WW, van Krieken JH, Huh J, Zhao X, Ponzoni M, Ferreri AJ, Bertoni F, Farnen JP, Moller MB, Piris MA, Winter JN, Medeiros LJ, Young KH: Clinical implications of phosphorylated STAT3 expression in de novo diffuse large B-cell lymphoma. Clin Cancer Res 2014, 20:5113-5123

30. Xu-Monette ZY, Dabaja BS, Wang X, Tu M, Manyam GC, Tzankov A, Xia Y, Zhang L, Sun R, Visco C, Dybkaer K, Yin L, Chiu A, Orazi A, Zu Y, Bhagat G, Richards KL, Hsi ED, Choi WW, van Krieken JH, Huh J, Ponzoni M, Ferreri AJ, Moller MB, Parsons BM, Zhao X, Winter JN, Piris MA, McDonnell TJ, Miranda RN, Li Y, Medeiros LJ, Young KH: Clinical features, tumor biology, and prognosis associated with MYC rearrangement and Myc overexpression in diffuse large B-cell lymphoma patients treated with rituximab-CHOP. Mod Pathol 2015, 28:1555-1573

31. Xia Y, Xu-Monette ZY, Tzankov A, Li X, Manyam GC, Murty V, Bhagat G, Zhang S, Pasqualucci L, Visco C, Dybkaer K, Chiu A, Orazi A, Zu Y, Richards KL, Hsi ED, Choi WW, van Krieken JH, Huh J, Ponzoni M, Ferreri AJ, Moller MB, Parsons BM, Winter JN, Piris MA, Westin J, Fowler N, Miranda RN, Ok CY, Li Y, Li J, Medeiros LJ, Young KH: Loss of PRDM1/BLIMP-1 function contributes to poor prognosis of activated B-cell-like diffuse large B-cell lymphoma. Leukemia 2017, 31:625-636

32. Xu-Monette ZY, Wu L, Visco C, Tai YC, Tzankov A, Liu WM, et al: Mutational profile and prognostic significance of TP53 in diffuse large B-cell lymphoma patients treated with R-CHOP: report from an International DLBCL Rituximab-CHOP Consortium Program Study. Blood 2012, 120:3986-3996

33. Tzankov A, Xu-Monette ZY, Gerhard M, Visco C, Dirnhofer S, Gisin N, Dybkaer K, Orazi A, Bhagat G, Richards KL, Hsi ED, Choi WW, van Krieken JH, Ponzoni M, Ferreri AJ, Ye Q, Winter JN, Farnen JP, Piris MA, Moller MB, You MJ, McDonnell T, Medeiros LJ, Young KH: Rearrangements of MYC gene facilitate risk stratification in diffuse large B-cell lymphoma patients treated with rituximab-CHOP. Mod Pathol 2014, 27:958-971

34. Pham LV, Fu L, Tamayo AT, Bueso-Ramos C, Drakos E, Vega F, Medeiros LJ, Ford RJ: Constitutive BR3 receptor signaling in diffuse, large B-cell lymphomas stabilizes nuclear factor-kappaB-inducing kinase while activating both canonical and alternative nuclear factor-kappaB pathways. Blood 2011, 117:200-210

35. Simioni C, Neri LM, Tabellini G, Ricci F, Bressanin D, Chiarini F, Evangelisti C, Cani A, Tazzari PL, Melchionda F, Pagliaro P, Pession A, McCubrey JA, Capitani S, Martelli AM: Cytotoxic activity of the novel Akt inhibitor, MK-2206, in T-cell acute lymphoblastic leukemia. Leukemia 2012, 26:2336-2342

36. Hein AL, Ouellette MM, Yan Y: Radiation-induced signaling pathways that promote cancer cell survival (review). Int J Oncol 2014, 45: $1813-1819$

37. Koo J, Yue P, Deng X, Khuri FR, Sun SY: mTOR complex 2 stabilizes Mcl-1 protein by suppressing its glycogen synthase kinase 3dependent and SCF-FBXW7-mediated degradation. Mol Cell Biol 2015, 35:2344-2355

38. Bonavida B: Rituximab-induced inhibition of antiapoptotic cell survival pathways: implications in chemo/immunoresistance, rituximab unresponsiveness, prognostic and novel therapeutic interventions. Oncogene 2007, 26:3629-3636

39. Winiarska M, Bojarczuk K, Pyrzynska B, Bil J, Siernicka M, Dwojak M, Bobrowicz M, Miazek N, Zapala P, Zagozdzon A, Krol M, Syta A, Podszywalow-Bartnicka P, Pilch Z, DabrowskaIwanicka A, Juszczynski P, Efremov DG, Slabicki M, Zenz T, Le Roy A, Olive D, Rygiel TP, Leusen JH, Golab J: Inhibitors of SRC kinases impair antitumor activity of anti-CD20 monoclonal antibodies. MAbs 2014, 6:1300-1313

40. Fransecky L, Mochmann LH, Baldus CD: Outlook on PI3K/AKT/mTOR inhibition in acute leukemia. Mol Cell Ther 2015, 3:2

41. Martelli AM, Tabellini G, Bressanin D, Ognibene A, Goto K, Cocco L, Evangelisti C: The emerging multiple roles of nuclear Akt. Biochim Biophys Acta 2012, 1823:2168-2178

42. Toulany M, Rodemann HP: Phosphatidylinositol 3-kinase/Akt signaling as a key mediator of tumor cell responsiveness to radiation. Semin Cancer Biol 2015, 35:180-190

43. Pfeifer M, Grau M, Lenze D, Wenzel SS, Wolf A, Wollert-Wulf B, Dietze K, Nogai H, Storek B, Madle H, Dorken B, Janz M, Dirnhofer S, Lenz P, Hummel M, Tzankov A, Lenz G: PTEN loss defines a PI3K/AKT pathway-dependent germinal center subtype of diffuse large B-cell lymphoma. Proc Natl Acad Sci U S A 2013, 110: $12420-12425$

44. Lenz G, Wright GW, Emre NC, Kohlhammer H, Dave SS, Davis RE, Carty S, Lam LT, Shaffer AL, Xiao W, Powell J, Rosenwald A, Ott G, Muller-Hermelink HK, Gascoyne RD, Connors JM, Campo E, Jaffe ES, Delabie J, Smeland EB, Rimsza LM, Fisher RI, Weisenburger DD, Chan WC, Staudt LM: Molecular subtypes of diffuse large B-cell lymphoma arise by distinct genetic pathways. Proc Natl Acad Sci U S A 2008, 105:13520-13525

45. Abubaker J, Bavi PP, Al-Harbi S, Siraj AK, Al-Dayel F, Uddin S, AlKuraya K: PIK3CA mutations are mutually exclusive with PTEN loss in diffuse large B-cell lymphoma. Leukemia 2007, 21:2368-2370

46. Carpten JD, Faber AL, Horn C, Donoho GP, Briggs SL, Robbins CM, Hostetter G, Boguslawski S, Moses TY, Savage S, Uhlik M, Lin A, Du J, Qian YW, Zeckner DJ, Tucker-Kellogg G, Touchman J, Patel K, Mousses S, Bittner M, Schevitz R, Lai MH, Blanchard KL, Thomas JE: A transforming mutation in the pleckstrin homology domain of AKT1 in cancer. Nature 2007, 448: 439-444

47. Noguchi S, Yasui Y, Iwasaki J, Kumazaki M, Yamada N, Naito S, Akao Y: Replacement treatment with microRNA-143 and -145 induces synergistic inhibition of the growth of human bladder cancer cells by regulating PI3K/Akt and MAPK signaling pathways. Cancer Lett 2013, 328:353-361

48. Tung YT, Lu YL, Peng KC, Yen YP, Chang M, Li J, Jung H, Thams S, Huang YP, Hung JH, Chen JA: Mir-17 approximately 92 governs motor neuron subtype survival by mediating nuclear PTEN. Cell Rep 2015, 11:1305-1318

49. Altomare DA, Zhang L, Deng J, Di Cristofano A, Klein-Szanto AJ, Kumar R, Testa JR: GSK690693 delays tumor onset and progression in genetically defined mouse models expressing activated Akt. Clin Cancer Res 2010, 16:486-496

50. Sangai T, Akcakanat A, Chen H, Tarco E, Wu Y, Do KA, Miller TW, Arteaga CL, Mills GB, Gonzalez-Angulo AM, Meric-Bernstam F: Biomarkers of response to Akt inhibitor MK-2206 in breast cancer. Clin Cancer Res 2012, 18:5816-5828

51. Gregory MA, Qi Y, Hann SR: Phosphorylation by glycogen synthase kinase-3 controls c-myc proteolysis and subnuclear localization. J Biol Chem 2003, 278:51606-51612

52. Arita K, Tsuzuki S, Ohshima K, Sugiyama T, Seto M: Synergy of Myc, cell cycle regulators and the Akt pathway in the development of aggressive B-cell lymphoma in a mouse model. Leukemia 2014, 28 : $2270-2272$

53. Zhao L, Lee JY, Hwang DH: The phosphatidylinositol 3-kinase/Akt pathway negatively regulates Nod2-mediated NF-kappaB pathway. Biochem Pharmacol 2008, 75:1515-1525 